\title{
DIFFERENT CLINICAL EXPRESSION OF ANXIETY DISORDERS IN CHILDREN AND ADOLESCENTS: ASSESSMENT AND TREATMENT
}

Nada Pop-Jordanova

Macedonian Academy of Sciences and Arts, Skopje, Republic of Macedonia

Corresponding author: Nada Pop-Jordanova, Bul Krste Misirkov br.2, P.O.Box 428, 1000 Skopje, Republic of Macedonia, e-mail: popjordanova.nadica@gmail.com

\section{ABSTRACT}

Background: Fearful and anxious behaviour is especially common in children, when they come across new situations and experiences. The difference between normal worry and an anxiety disorder is in the severity and in the interference with everyday life and normal developmental steps. Many longitudinal studies in children suggest that anxiety disorders are relatively stable over time and predict anxiety and depressive disorders in adolescence and adulthood. For this reason, the early diagnostic and treatment are needed.

Researchers supposed that anxiety is a result of repeated stress. Additionally, some genetic, neurobiological, developmental factors are also involved in the aetiology.

Methods and subjects: The aim of this article is to summarize and to present our own results obtained with the assessment and treatment of different forms of anxiety disorders in children and adolescents such as: Posttraumatic Stress Disorder (PTSD), Obsessive Compulsive Disorder (OCD), Dental anxiety, General Anxiety Disorder (GAD), and Anxious-phobic syndrome. Some results are published separately in different journals.

a) Post Traumatic Stress Disorder (PTSD) in 10 young children aged $9 \pm 2,05 \mathrm{y}$. is evaluated and discussed concerning the attachment quality.

b) The group with OCD comprises 20 patients, mean age 14,5 $\pm 2,2$ years, evaluated with Eysenck Personality Questionnaire (EPQ), Child behaviour Checklist (CBCL), K-SADS (Schedule for Affective Disorders and Schizophrenia for School age children), Beck Depression Inventory (BDI), SCWT (Stroop Colour Word task), WCST (Wisconsin Card Scoring test).

c) Dental stress is evaluated in a group of 50 patients; mean age for girls $11,4 \pm 2,4$ years; for boys $10,7 \pm$ 2,6 years, evaluated with (General Anxiety Scale (GASC), and Eysenck Personality Questionnaire (EPQ).

d) Minnesota Multiphasic Personality Inventory ( MMPI) profiles obtained for General Anxiety Disorder in 20 young females and 15 males aged $25,7 \pm 5,35$ years, and a group with Panic attack syndrome $\mathrm{N}=15$ aged 19,3 $\pm 4,9$ years are presented and discussed by comparison of the results for healthy people.

e) Heart Rate Variability (HRV) was applied for assessment and treatment in 15 anxious-phobic patients, mean age $12,5 \pm 2,25$ years and results are compared with other groups of mental disorder.

Results: Children with PTSD showed a high level of anxiety and stress, somatization and behavioural problems (aggression, impulsivity, non-obedience and nightmares), complemented by hypersensitive and depressed mothers and misattachment in the early period of infancy. Consequently, the explanation of the early predisposition to PTSD was related to be the non-developed Right Orbital Cortex. The later resulted from insecure attachment confirmed in all examined children.

The obtained neuropsychological profile of children with OCD confirmed a clear presence of obsessions and compulsions, average intellectual capacities, but the absence of depressive symptoms. Executive 
functions were investigated through Event Related Potentials on Go/NoGo tasks. Results showed that no significant clinical manifestations of cognitive dysfunction among children with OCD in the early stage of the disorder are present, but it could be expected to be appearing in the later stage of the disorder if it is no treated.

In a study of 50 children randomly selected, two psychometric instruments were applied for measuring general anxiety and personal characteristics. It was confirmed that there was presence of significant anxiety level (evaluated with GASC) among children undergoing dental intervention. The difference in anxiety scores between girls and boys was also confirmed (girls having higher scores for anxiety). Results obtained with EPQ showed low psychopathological traits, moderate extraversion and neuroticism, but accentuated insincerity (L scale). L scales are lower by increasing of age, but P scores rise with age, which can be related to puberty. No correlation was found between personality traits and anxiety except for neuroticism, which is positively correlated with the level of anxiety.

The obtained profiles for MMPI-201 in a group of patients with general anxiety are presented as a figure. Females showed only Hy peak, but in the normal range. However, statistics confirmed significant difference between scores in anxiety group and control ( $t=2,25164 ; p=0,038749)$. Males showed Hs-Hy-Pt peaks with higher (pathological) scores, related to hypersensitivity of the autonomic nervous system, as well as with manifested anxiety. Calculation confirmed significant difference between control and anxiety in men $(\mathrm{t}=15.13, \mathrm{p}=0.000)$.

Additionally, MMPI profiles for patients with attack panic syndrome are also presented as a figure. Control scales for females showed typical V form (scales 1 and 3 ) related to conversing tendencies. In addition, females showed peaks on Pt-Sc scales, but in normal ranges. Pathological profile is obtained in males, with Hy-Sc peaks; this profile corresponds to persons with regressive characteristics, emotionally instable and with accentuated social withdraw.

Heart rate variability (HRV) is a measure of the beat to beat variability in heart rate, related to the work of autonomic nervous system. It may serve as a psychophysiological indicator for arousal, emotional state and stress level. We used HRV in both, the assessment and biofeedback training, in a group of anxious-phobic and obsessive-compulsive school children. Results obtained with Eysenck Personality Questionnaire showed significantly higher psychopathological traits, higher neuroticism and lower lie scores. After 15 session HRV training very satisfying results for diminishing stress and anxiety were obtained.

Keywords: anxiety, clinical signs, children, adolescents, assessment, treatment 


\section{INTRODUCTION}

Anxiety comprises an unpleasant state ranging from mild uneasiness to intense fear. It is presented with physical and psychological symptoms, which could inhibit normal thought and disrupt normal everyday activities. Anxiety disorders are widespread in today's society. Based on statistical data, it is supposed that one person in four people has had an experience with some form of anxiety in their lifetime. The severity of anxiety disorder can range from moderate and manageable to debilitating.

Fearful and anxious behaviour is especially common in children, when they come across new situations and experiences during their developmental process. The difference between normal worry and an anxiety disorder is in the severity and in the interference with everyday life and normal developmental steps.

Anxiety comprises many phenotypes and clinical descriptions. It is routinely partitioned into disorders of general anxiety (GAD), panic, phobia, and obsessive-compulsive disorder (OCD). Two main classifications are used for diagnosis of anxiety disorders: International Classification of Diseases, 10th Revision (ICD10), and Diagnostic and Statistical Manual of Mental Disorders (DMS-5).

In the fifth edition of the Diagnostic and Statistical Manual of Mental Disorders (DSM-5) edited in 2013, the following anxiety disorders are notified: Separation Anxiety Disorder, Selective Mutism, Specific Phobia, Social Anxiety Disorder (Social Phobia), Panic Disorder, Panic Attack Specifier, Agoraphobia, Generalized Anxiety Disorder, Substance/Medication-Induced Anxiety Disorder, Anxiety Disorder Due to Another Medical Condition, Other Specified Anxiety Disorder and Unspecified Anxiety Disorder.

According DMS-5, at least three of the following physical or cognitive symptoms are needed for diagnosis: Edginess or restlessness; Tiring easily (more fatigued than usual); Impaired concentration (feeling as though the mind goes blank); Irritability (which may or may not be observable to others); Increased muscle aches or sorenes; Difficulty sleeping (due to trouble falling asleep or staying asleep, restlessness at night, or unsatisfying sleep). In children, only one symptom is necessary for a diagnosis of GAD.

Researchers supposed that anxiety is a result of repeated stress. Additionally, some genetic, neurobiological, developmental and environmental factors are also involved in the aetiology.

The theories explaining the causes of anxiety can be divided in three main groups: a) Physiological theories, based on measurements, showed hyperarousal of the central nervous system which make more excited reaction and slow adaptation to normal events. b) Psychoanalytical approach explain the anxiety as a repressed, unresolved childhood experiences, related to the quality of attachment. c) Behavioural theories describe the anxiety as a learned response to pain or mental discomfort.

Genetic epidemiology has assembled convincing evidence that anxiety and related disorders are influenced by genetic factors, where the genetic component is highly complex. Some data confirmed that children manifest anxiety in situation where their parents are anxious, as well. Recent study from the University of Wisconsin-Madison shows how an over-active brain circuit, involving three brain areas inherited from generation to generation, may set the stage for developing anxiety and depressive disorders [1]. It was shown that elevated activity in the prefrontal - limbic - midbrain circuit is involved in mediating the in-born risk for extreme anxiety and anxious temperament that can be observed in early childhood. Additionally, researchers confirmed that about half of children who show extreme anxiety develop stress-related psychiatric disorders later in life. The duplication of a part of chromosome 15 is supposed to be a major genetic factor of susceptibility for panic and phobic disorders, and its identification may have important implications for psychiatry and health [2].

In Evolution Letters (2018) recently Japanese authors published that they have discovered SLC18A1 (VMAT1), which encodes vesicular monoamine transporter 1 , as one of the genes evolved through natural selection in the human lineage. VMAT1 is mainly involved in the transport of neurochemicals, such as serotonin and dopamine in the body, and its malfunction leads to various psychiatric disorders. VMAT1 has variants consisting of two different amino acids, threonine (136 Thr) and isoleucine (136Ile), at site 136. Several other studies have shown that these variants are associated with psychiatric 
disorders, including schizophrenia, bipolar disorder, anxiety, and neuroticism (as a personality trait). It has been known that individuals with 136 Thr tend to be more anxious and more depressed and have higher neuroticism scores. With the achievement of the sequencing of the human genome, and the active development of techniques for large-scale molecular genetic analysis of the genome, there is now hope for the identification of the contribution of particular genes to the development of these disorders.

Some neuroanatomical specifics are related to anxiety disorders such as: changes in the size of the amygdala and regions of the temporal lobe in close proximity to the amygdala, smaller regional grey matter volume in the right hippocampus, as well as smaller regional brain volume in the left anterior prefrontal cortex, especially in females. Using brain imaging techniques, it was found that functional connectivity between two regions of the central extended amygdala is associated with anxious temperament in pre-adolescent animals. Having in mind the similarity with human brain, the same pathway for anxiety in children was postulated. In this context, research relates anxiety with some new mutation of different genes. Modest, but measurable link between anxiety-related behaviour and the gene that controls the brain's ability to use an essential neurochemical called serotonin is found. Additionally, lower densities of peripheral GABA receptors are found in children with separation anxiety [3].

The growing evidence for the genetic bases of anxiety disorders has suggested that a single gene may contribute additively and interchangeably to vulnerability to anxiety disorders, but its contribution is neither necessary, nor sufficient for manifesting the expression of the phenotype of an anxiety disorder. Bearing this in mind, many studies have examined potential gene by environment (GxE) interactions that underlie anxiety disorder vulnerability and symptomatology.

In this context, additionally to genetics, several variables have been identified as potential risk factors for anxiety disorders, such as parental style and psychopathology, behaviourally inhibited temperament, or early life traumatic events (e.g., loss of parents, parental divorce, physical and sexual abuse). Stress in small children is most often seen as an overt physical reaction: crying, sweating palms, running away, aggressive or defensive outbursts, rocking and self-comforting behaviours, headaches and stomach aches, nervous fine motor behaviours (e.g., hair twirling or pulling, chewing and sucking, biting of skin and fingernails), toileting accidents, and sleep disturbances [4].

Later, information load, opportunities and high competitiveness are some of the important sources of stress which create tension, fear, anger and anxiety together with high expectations of parents and teachers, academic pressures, unrealistic ambitions, and limited employment in youngsters. Some studies indicate that psychosomatic symptoms are common in children with stress, the most frequent being: tiredness, stomach ache, headache, and psychological problems that can be triggered by different situations in the child's life, such as school demands and administration of time for homework. In Fig 1 diagram of genetic factors interacting with developmental stress to impact vulnerability to develop anxiety and other psychopathology, adopted from Lancet is presented [5].

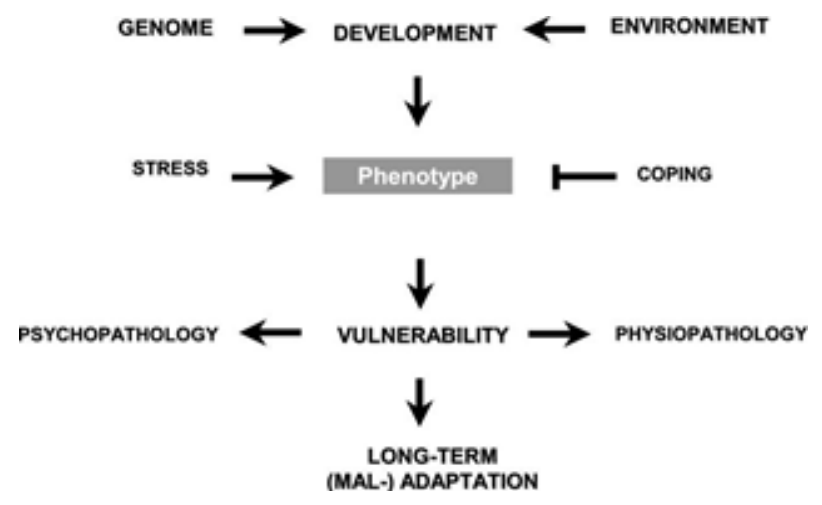

Fig 1. Diagram of genetic factors interacting with developmental stress to impact vulnerability to develop anxiety and other psychopathology.

(Adopted from Lancet, 2002)

Concerning the onset, the earliest age of the manifestation has been consistently found for separation anxiety disorder and some types of specific phobias (particularly the animal, blood injection injury, and environmental type), with most cases emerging in childhood before the age of 12 years, followed by the onset of social phobia with incidences in late childhood and throughout adolescence, with very few cases emerging after the age of 25. Panic disorder, agoraphobia, and GAD, in contrast, have their core periods for first onset in later adolescence with further first incidences in early adulthood, despite the fact that some cases, especially with panic attacks, might occur as early as at the age of 12 years or before. In the Fig. 2 


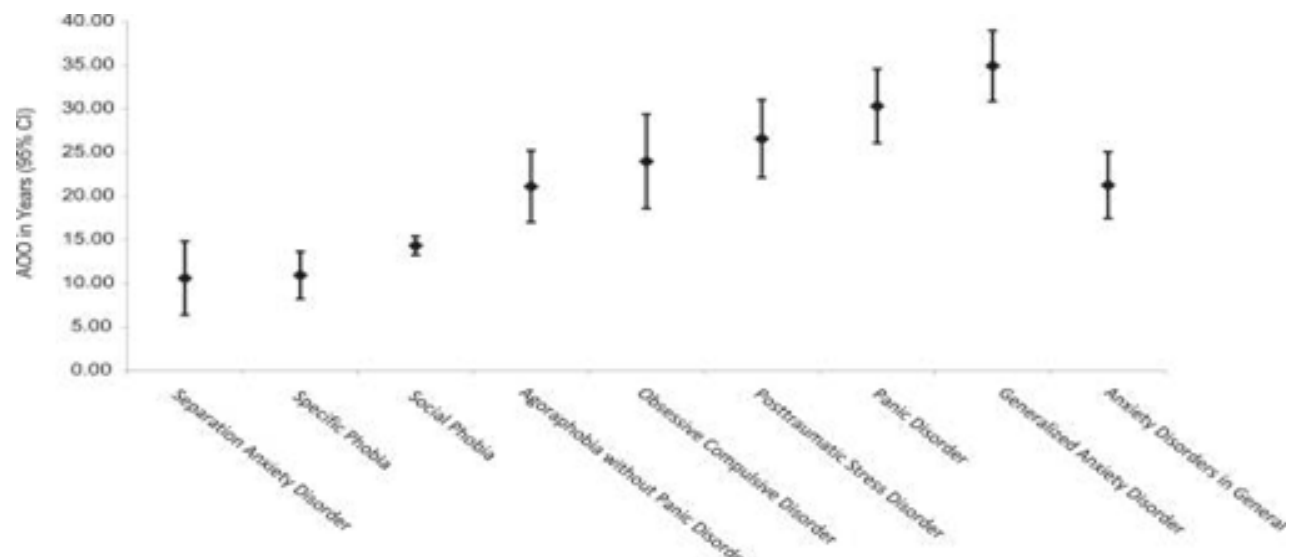

Fig. 2. Mean age of onset estimates for anxiety disorders

(Used from the Meta analysis of Jasmijn M. de Lijster, et al, 2017)

mean age of onset estimated for anxiety disorders is presented based on Meta analysis of de Lijster (2017) [6].

Many longitudinal studies in children suggest that anxiety disorders are relatively stable over time and predict anxiety and depressive disorders in adolescence and adulthood. For this reason, the early diagnostic and treatment are needed. The comorbidity of anxiety disorders with other psychiatric disorders, particularly mood, has been observed and accepted for many decades.

The aim of the review is to present our own results obtained with the assessment and treatment of different forms of anxiety disorders in children and adolescents such as: Posttraumatic stress disorder (PTSD), obsessive compulsive disorder (OCD), Dental anxiety, General anxiety disorder (GAD), and Anxious-phobic syndrome. Additionally, results of heart rate variability (HRV) used as a tool for assessment and treatment will be presented. Additionally, our own formula for spectral mean frequency (brain rate) was applied to calculate arousal in general anxiety group.

\section{REFERENCES}

1. Intergenerational Neural Mediators of Early-Life Anxious Temperament, Proceedings of the National Academy of Sciences, 2015. www.pnas. org/cgi/doi/10.1073/pnas.1508593112).

2. Gratacôs Monica., Nadal Marga, Martin-Santos Rocio., et al. "A polymorphic genomic duplication on human chromsome 15 is a susceptibility factor for panic and phobic disorders". Cell. 106, (2001):367-379.

3. Nuss Philippe. "Anxiety disorders and GABA neurotransmission: a disturbance of modulation". Neuropsychiatr Dis Treat. 11, (2015): 165-175.
4. Scott Elizabeth. "Stress Management. Be mindful of stress relief" Oct (2007): Available from http://stress.about.com/.

5. Richie Poulton, Avshalom Caspi, Barry J. Milne, Murray Thomson, Alan Taylor, Malcolm R. Sears, and Terrie E. Moffitt. "Association between children's experience of socioeconomic disadvantage and adult health: a life-course study". Lancet. 2002;360: 1640-5.

6. Jasmijn M. de Lijster, Bram Dierckx, Elisabeth M.W.J. Utens, Frank C. Verhulst, Carola Zieldorff, Gwen C. Dieleman, and Jeroen S. Legerstee. "The Age of onset of anxiety disorder. A Meta-analysis". Can J Psychiatry.; 62, 4 (2017) : 237-246.

\section{METHODS AND PARTICIPANTS}

Several groups of children and adolescents are elaborated:

A) Post Traumatic Stress Disorder (PTSD) in 10 young children aged $9 \pm 2,05 \mathrm{y}$. is evaluated and discussed concerning the attachment quality.

(B) The group with Obsessive-Compulsive Disorder (OCD) comprises 20 patients, mean age $14,5 \pm 2,2$ years, evaluated with Eysenck Personality Questionnaire (EPQ), Child Behaviour Checklist (CBCL), K-SADS (Schedule for Affective Disorders and Schizophrenia for School age children), Beck Depression Inventory (BDI), Stroop Colour Word Task (SCWT), and Wisconsin Card Scoring Test (WCST).

(C) Dental stress is evaluated in a group of 50 patients; mean age for girls $11,4 \pm 2,4$ years; for boys $10,7 \pm 2,6$ years, evaluated with Gen- 
eral Anxiety Scale (GASC), Eysenck Personality Questionnaire (EPQ).

(D) Minnesota Multiphasic Personality Inventory (MMPI) was used for the assessment of a group with General Anxiety Disorder, comprising 20 young females and 15 males, mean age 25 , $7 \pm 5,35$ years, and a group of 15 patients with Panic attack syndrome, aged 19, $3 \pm 4,9$ years.

(E) Heart Rate Variability (HRV) was applied in 15 anxious-phobic patients, mean age $12,5 \pm 2,25$ years and 10 children with obsessive-compulsive manifestations (OCD), mean age $14.5 \pm 2.20$; results are compared with the control.

(H) Calculation of Brain rate parameter in 40 anxious patients with mean age $12 \pm 3$, 5 years shows specific finding in laterality and brain location.

In this research several psychometric instruments are used. Short description is below.

Child Behaviour Check List (CBCL) - is a questionnaire for behaviour assessment filled out by the parents of the children. It is combined with 113 questions related to the assessment of depression, social communication or withdrawal, somatic complaints, schizoid behaviour, hyperactivity, problems in the psychosexual development, delinquent and aggressive conduct, problems in the conduct, problems with the judgment and level of anxiety. This questionnaire is adjusted based on the child's age and gender [1].

Eysenck Personality Questionnaire (EPQ) - is a self-report personality inventory which assumes three basic factors (extraversion/ introversion, neuroticism and psychopathology). The EPQ was developed by Hans J. Eysenck and his colleagues $[2,3]$.

Obtained high E scores indicate extraversion, and individuals tend to be outgoing, impulsive, uninhibited, having many social contacts, and often taking part in group activities. Typically, the extravert is highly social, likes gatherings, has many friends, needs to have people to talk to and dislikes solitary pursuits such as reading, studying, and contemplation. From the neurological point of view, extraverts have under arousal as a basic characteristic of brain activity. By contrast, the introvert tends to be quiet, retiring and studious. The typical introvert is reserved and distant, except to intimate friends, tends to plan ahead and usually distrusts acting on impulse. Such persons prefer a well-arranged existence, keep their feelings well controlled, and are more passive than aggressive. Generally reliable, although somewhat pessimistic, typical introverts seldom lose their temper and tend to place great value on ethical standards. Introverts have over arousal as a basic brain activity.

High $\mathrm{N}$ scores indicate strong emotional lability and over activity. Persons with high N scores tend to be emotionally over responsive, and encounter difficulties in calming down. Such persons complain of vague somatic upsets, and report many worries, anxieties, and irritating emotional feelings. They may develop neurotic disorders when under stress, which fall short of actual neurotic collapses. However, high $\mathrm{N}$ scores do not preclude such persons functioning adequately in the family, school and work situations.

Persons with high $\mathrm{P}$ scores are inclined toward being cruel, inhumane, socially indifferent, hostile, aggressive, and not considerate of danger, and intolerant. They show a propensity towards making trouble for others, belittling, acting disruptively, and lacking in empathy. The physiological basis suggested by Eysenck for psychoticism is testosterone, with higher levels of psychoticism associated with higher levels of testosterone.

EPQ has an additional fourth scale, the lie (L) scale which is a measure of non-sincerity, when a person gives social available answers to show him/her as adaptable and without conflicts. EPQ has proven useful for numerous applications in human resources, career counselling, clinical settings and research. Our own experience with EPQ is very positive.

The General Anxiety Scale for Children $(G A S C)$ - is a 45 item yes/no scale for use with children in grades 1-9. It measures chronic, generalized anxiety. Obtained score of 12 or below ranks in the low anxiety range. A score of 12-20 ranks in the medium range. Any score above 20 signifies high anxiety. Scoring 15 or greater is a good indication that the child experiences considerable discomfort about the situation in which he/she is [4].

Stress-test - is simple (and very fast) yes/ no 20 items questionnaire, where the higher scores are related to higher stress level [5].

The Schedule for Affective Disorders and Schizophrenia for School-Age Children $(K-S A D S)$ - is a semi structural questionnaire for children between 6 and 18 years of age with the 
aim to generate DSM-IV diagnosis, such as the affective, psychotic and behaviour disorders [6].

The Stroop Colour Word Test, measures the mental vitality and flexibility, cognitive abilities to direct the attention, inhibition of automatic responses and initiation of correct ones [7].

The Wisconsin Card Sorting Test (WCST) - is a neuropsychological test for evaluation of the mental flexibility ("set-shifting" when the stimulus is changed), the attention, the working memory and visual processing [8].

Minnesota Multiphasic Personality Inventory (MMPI-201) - was used as a psychometric test for evaluating the personality profiles of people over 12 years. In this context, we used MMPI for evaluation of the personalities in people with general anxiety, as well as with attack panic syndrome [9].

Heart rate variability $(H R V)$ is a measure of the beat-to-beat variations in heart rate related to the work of autonomic nervous system. It may serve as a psychophysiological indicator for arousal, emotional state and stress level. We used this parameter in both, the assessment and biofeedback training, for dealing with some groups of common mental health problem in school children [10].

\section{REFERENCES}

1. Achenbach, Thomas. Manual for the Child Behaviour Checklist/4-18 and 1991 Profile. Burlington, VT: University of Vermont, Department of Psychiatry (1991).

2. Eysenck Hanse, Eysenck Sybile. Manual of the Eysenck Personality Questionnaire, London, Hodder \& Stoughton (1975).

3. Eysenck Hanse and Eysenck Sybile. Eysenck Personality Questionnaire - Revised (EPQ-R); Hodder \& Stoughton (1991).

4. Sarason, Seymour. Anxiety in Elementary Schoolchildren (co-authored with Kenneth S. Davidson, Frederick F. Lighthall, and Richard R. Waite) (1960).

5. Susan Spence, Paula Barrett, Cynthia Turner. "Psychometric Properties of the Spence Children's Anxiety Scale with Young Adolescents". J Anxiety Disorder 17, 6 (2003): 605-625.

6. Ridley Stroop. "Studies of interference in serial verbal reactions". Journal of Experimental Psychology; 18 (1935): 643-662.

7. Chambers J, Puig-Antich Joakim, Hirsch M, Paez P, Ambrosini J, Tabrizi A, Davies M. "The assessment of affective disorders in children and adolescents by semi-structured interview. Test-retest reliability of the schedule for affective disorders and schizophrenia for school-age children, present episode version". Arch Gen Psychiatry; 42 (1985): 696-702.

8. Berg Esta. "A simple objective technique for measuring flexibility in thinking", J. Gen. Psychol.; 39 (1948): 15-22.

9. Arbisi Paule, Butcher James. "Relationship between personality and health symptoms: Use of the MMPI-2 in medical assessments". International Journal of Clinical and Health Psychology, Vol. 4, No 3, (2004): 571- 595.

10. Heart Math Freeze-Framer System. A Scientifically Proven Technique for Clear Decision Making and Improved Health, DOC Children, Planetary Publications, Boulder Creek, CA. Edited by Bruce Cryer (1998).

\section{(1) Posttraumatic Stress Disorder (PTSD) in young children}

Posttraumatic Stress Disorder (PTSD), is classified under anxiety disorders in both ICD10 and DMS-IV. In the DSM-5 (2013), PTSD is included in a new category named as 'Trauma and Stressor-Related Disorders'. Posttraumatic Stress Disorder, additionally, includes a new subtype for children younger than 6 years. This change is based on recent research detailing what PTSD looks like in young children. Adding the developmental subtype should help clinicians tailor treatment in a more age-appropriate and age-effective way.

All of the conditions included in this classification require exposure to a traumatic or stressful event as a main diagnostic criterion. In young children, the disorder is characterized by three main types of symptoms: re-experiencing the trauma through intrusive distressing recollections of the event, flashbacks, and nightmares. Children's responses to severe trauma may be more disorganized than in an adult and can involve agitated behaviour. In this context, their response may include intensive fear, helplessness or horror. The event must be persistently remembered and 'relived' with concomitant distress, particularly when current circumstances are associated with the original event.

Main clinical characteristics of PTSD are intrusive and distressing recollections of the event seen by them in play, nightmares, re-enacting the event behaviourally, avoidance of stimuli 
associated with the trauma, increased arousal, visual imagery (flashbacks), and especially in adolescents increasing risk of irritable moods and sleep deprivation. It was noticed that girls are more susceptible to PTSD than boys.

There are no precise epidemiological data about PTSD in children. Some studies in the USA show that about $15 \%$ to $43 \%$ of girls and $14 \%$ to $43 \%$ of boys go through at least one trauma during their life. Of those children and teens who have had a trauma, $3 \%$ to $15 \%$ of girls and $1 \%$ to $6 \%$ of boys develop PTSD. Rates of PTSD are higher for certain types of trauma survivors. In war conditions the incidence is about $11.5 \%$, while after some accidents the incidence is higher, approaching $30 \%$ [1].

The right orbitofrontal cortex (ROFC) has been pointed out as crucial in the regulation of emotions and the autonomous nervous system (ANS). Consequently, infants with attachment problems have a problematic $\mathrm{ROFC}$ and are more predisposed to PTSD. ROFC is not on line in birth. It develops only through interaction with another self, another brain. The engagement and attunement of the mother stimulate positive emotions and develop the ventral tegmental dopaminergic pathways of excitatory arousal. Thousands of positive interactions are needed to develop this system regulation of the sympathetic system. In the second year parasympathetic inhibiting circuits become internalised. Infants experience a shame-based inhibition of unbounded excitation. These negative experiences develop the lateral tegmental parasympathetic noradrenergic system. For this reason, the caregiver must avoid toxic shame in the first year of the child's life. A poorly attuned mother does not allow infant self-promotion, and severe humiliation or aggressive interaction produce excessive anxiety and infantile rage responses. Flexible switching between these two systems (Sy and PaSy) allows successful methods for rudimentary coping with stress [2].

Within the attachment relationship the mother is shaping the infant 's coping systems (brain-body reaction to the stress). The model of Bowlby, enriched by the neurobiological findings of Shore, shows how early social emotional interactions within the attachment relationship impact the experience-dependent maturation of the baby's brain. This is partly determined by genetic factors (encoded in the temperament) and partly determined by early socio-affective ex- perience (nature of caregiver). It is obvious that the brain growth spurts continue from the end of the last trimester of pregnancy through the first two years of life. Both DNA and RNA levels in the cortex increase over the first year, and the maturation of the brain is experience-dependent. Thus, an integrative, interdisciplinary approach to the development of the child is needed $[3,4]$.

Interaction between mothers and babies plays an important role in the formation of attachment and in determining maternal response to the infant's signals. In this context, there is research evidence that breast-feeding mothers differ from bottle-feeders in satisfaction with the experience, in acceptance of the maternal model and emotional investment in the infant $[5,6]$.

Attachment is a term firstly used by John Bowlby [7] to describe the affective bond that develops between an infant and a primary caregiver. Bowlby described the infant as biologically predisposed to use the caregiver as a secure base, while exploring the environment. The caregiver's response to such bids helps shape the attachment relationship into a pattern of interaction that develops over the first year of life. The history of this developing relationship between the infant and the caregiver allows the infant to begin to anticipate the caregiver's response to bids for comfort $[8,9,10]$.

Secure attachment arises out of responsive and sensitive parenting and is contrasted to adult neurosis. By studying a sample of unweaned babies and their mothers, Ainsworth et al. [6] discovered three different levels of attachment: securely attached, insecurely attached (avoidant, ambivalent and disorganised) and non-attached children.

In ICD-10 and DMS-IV two varieties of attachment disorders are recognised: a) non-attachment with emotional withdrawal, typically associated with abuse and b) non-attachment with indiscriminate sociability, most usually observed when children have been exposed to repeated changes of caregivers.

Generally, the findings do not support a strong genetic basis for PTSD. The strongest evidence for a genetic contribution to the disorder is the observation that only a subset of individuals will develop PTSD following trauma exposure. In addition, the most compelling evidence for genetic influences on PTSD comes from significant interactions between specific gene variants and environmental factors (e.g., homozygous $\mathrm{S}$ 
genotype for 5HTTLPR and low degree of social support in hurricane victims). The effect of genetics alone on PTSD has been shown to be quite minimal and, as such, the focus going forward should be on large-scale GxE examinations and potential epigenetic mechanisms.

We selected a group of 10 children manifesting PTSD diagnosed by ICD-10 criteria, mean age $12 \pm 3.05$ years, (girls 3 , boys 7 ). In our study boys were predominant, as opposed to other authors who noticed that girls are more susceptible to PTSD. Through anamnesis, symptomatology and psychometric evaluation we tried to reveal and explore the relationship between the earl y child experience (attachment bonding) and the degree of stress reaction.

Mothers are checked by Minnesota Multiphasic Personality Inventory (MMPI) and Child Behaviour Checklist (CBCL), while older children were examined by Eysenck Personality Questionnaire (EPQ) and State Anxiety Inventory (STAI).

As stressful events provoking PTSD were identified: in three cases - the death of family members (parent or grandparent), in three other cases - a car accident, and in four last cases - the war conditions (i.e. explosion of a bomb near the school).

The interview with mothers in all cases showed different types of insecure attachment. In two cases, the mother was still a psychiatric patient (severe depression), and in others some specific situations in the family were assumed to be the reason for insecure attachment.

All children manifested PTSD after a relatively small stress because of insecure attachment.

Results for CBCL - boys, illustrating behaviour problems, are presented in Figure 1. Generally, high internalising scores are obtained for all children, while externalising scores appeared to be high only in boys, with particularly accentuated aggression.

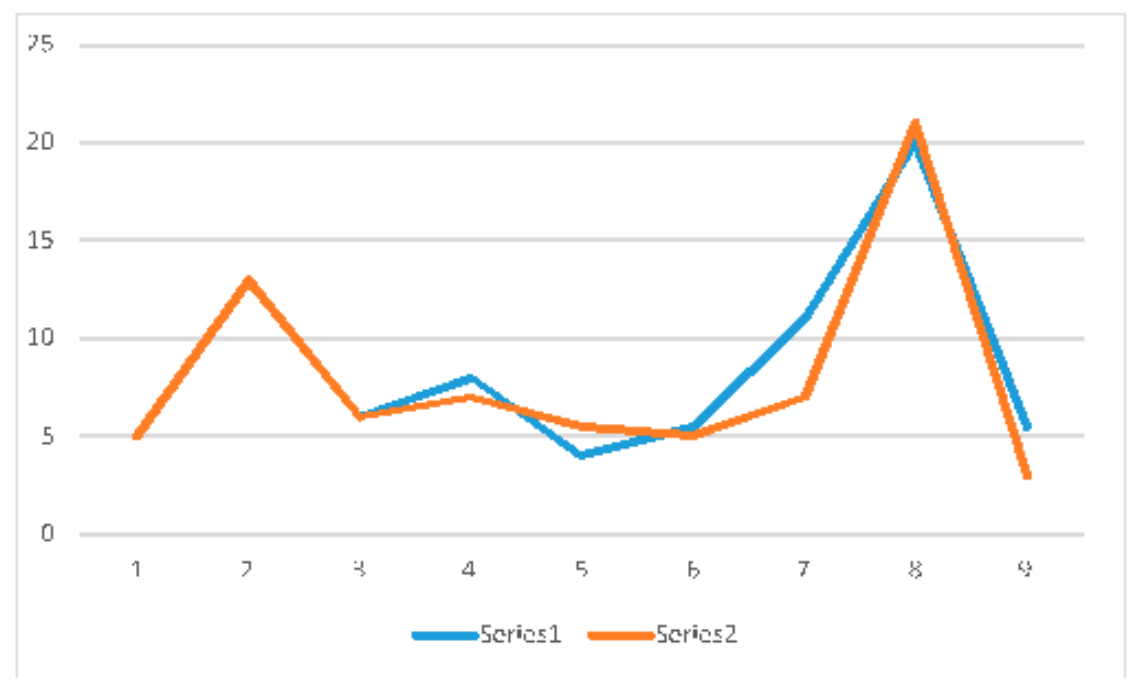

Fig. 1. Results obtained for CBCL-boys

(1. Anxious; 2. Depressed; 3. Uncommunicative; 4. Obsessive-compulsive; 5. Somatization; 6. Social withdrawal; 7. Hyperactive; 8. Aggressive; 9. Delinquent; series 1=norm; series $2=$ PTSD)
Results obtained for EPQ confirmed neurotic tendencies, introversion, psychopathologic traits and tendencies to social liability (Table I). The control group for EPQ consisted of 35 healthy school children, both sexes, matched by age. 
Table 1. Group's results for EPQ

\begin{tabular}{llll} 
Neuroticism $(\mathrm{N})$ & Extraversion $(\mathrm{E})$ & Social Liability $(\mathrm{L})$ & Psychopathology $(\mathrm{P})$ \\
\hline PTSD 17,4 $\pm 3,5$ & $9 \pm 2,3$ & $8,5 \pm 5,3$ & $12,5 \pm 4,3$ \\
Control $13 \pm 3,7$ & $16 \pm 2,7$ & $14 \pm 4,03$ & $6 \pm 3,003$ \\
t-test 3,55 $\mathrm{p}<0,01$ & t-test 7,07 $\mathrm{p}<0,01$ & t-test $2,93 \mathrm{p}<0,05$ & t-test 7,17 $\mathrm{p}<0,01$
\end{tabular}

Figure 3 presents results obtained from MMPI of mothers. High Hs scale confirms narcissism and hypochondriasis; while scores for other scales are related to expressed immaturity, impulsivity, anxiety and moderate depression.
In addition to the classical treatment of PTSD (behaviour-cognitive and play therapy) $[11,12,13]$ we introduced multimodal biofeedback application (Electro dermal and Neurofeedback) for both assessment and therapy [14, 15, 16, 17].

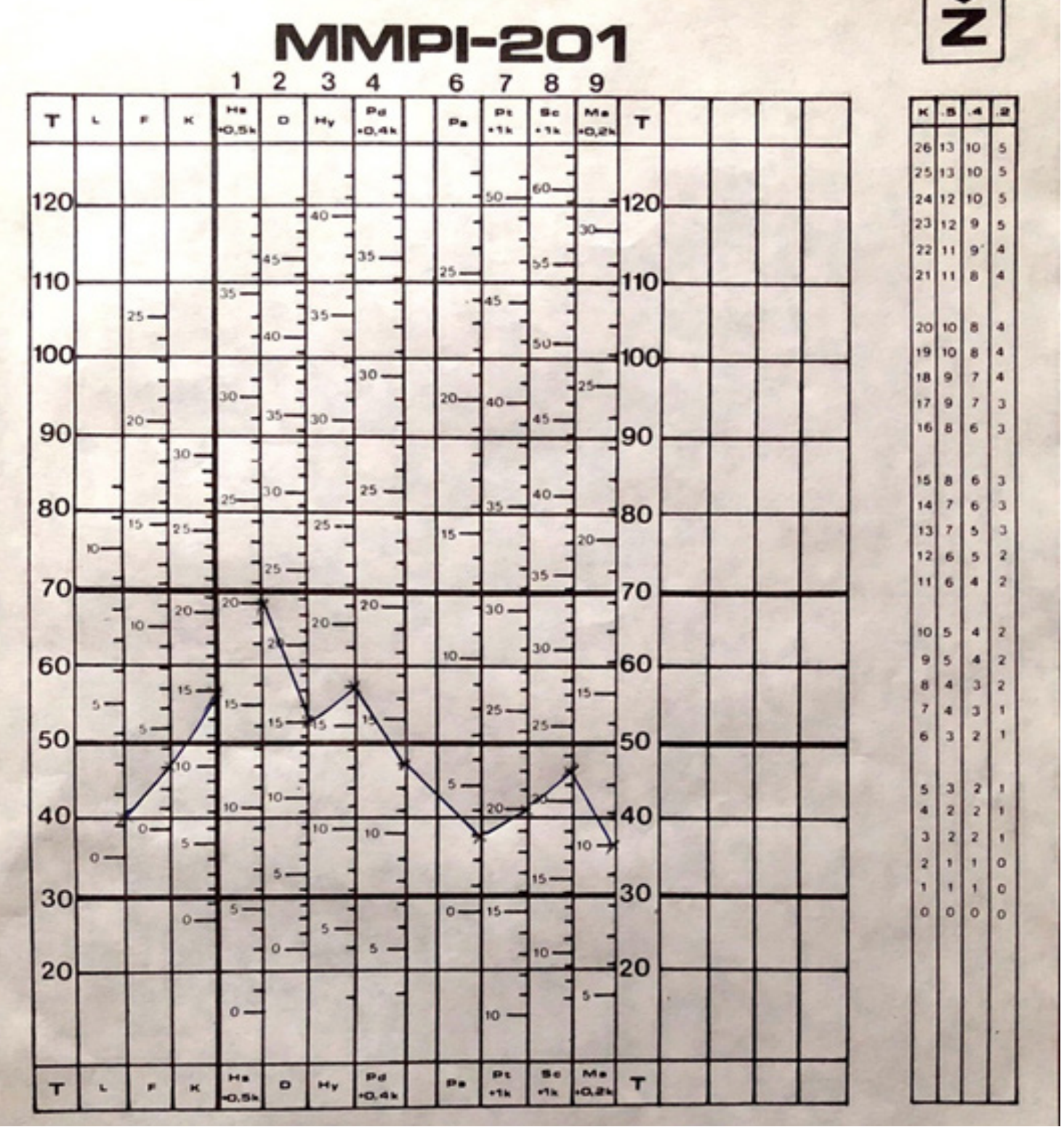

Fig 2. Results obtained for mother's MMPI

The evaluation of children with State Anxiety Inventory (STAI) showed mean values for anxiety level 39.5 (from max 45) for the whole group, which is related to very high actual anxiety.
Feedback is defined as a method of controlling the system by reinserting the results of its past performance, while biofeedback $(\mathrm{BF})$ is the method of learning self-control by back-reporting 
biological signals. BF has several modalities depending on the type of bio signals: electrodermal response (EDR), electromyography (EMG), electroencephalography (EEG), BVP (blood volume pulse), RWF (respiratory waveform), etc. Figure 3 shows the biofeedback process schematically.

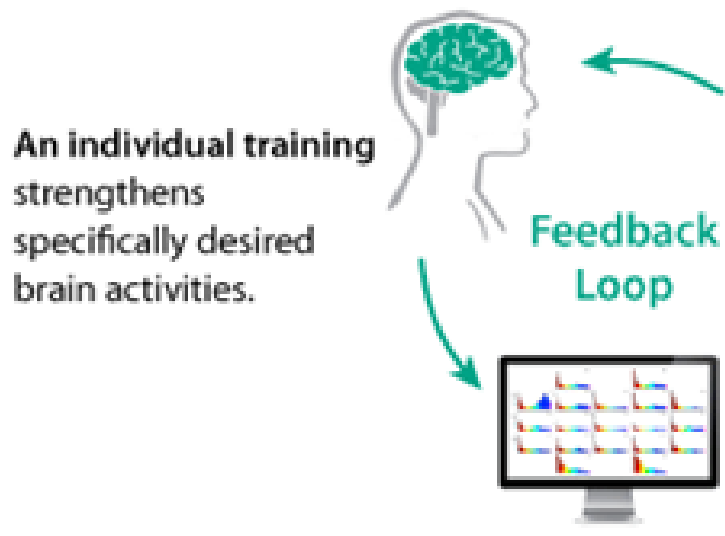

Figure 3. Schematic presentation of the biofeedback method

The EDR-biofeedback was used for assessment of the stress level, which is related to skin electric resistance. By the reduction of the stress-level by relaxation, the skin resistance increases. On the other hand, the recalling of a stressful event provokes the abatement of the curve, i.e. increasing stress-level, resistance decreases (Fig.4).
EDR BF are presented. The increase of the EDR resistance shows the relaxation after 20 sessions training. On the right, the change in SMR-NFB (in $\mu \mathrm{V}$ ) followed by lower arousal is presented.

In addition to EDR biofeedback, we used neurofeedback (EEG biofeedback) for stress re-

\section{A continuous audio-}
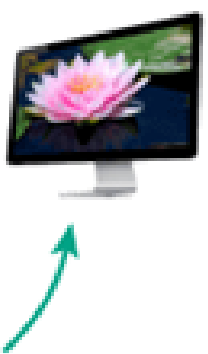
visual feedback stimulates the brain and inspires it to a maximum level of performance.

\section{Real-time information}

about brain activity patterns is the basis for an individual and effective Neurofeedback training.

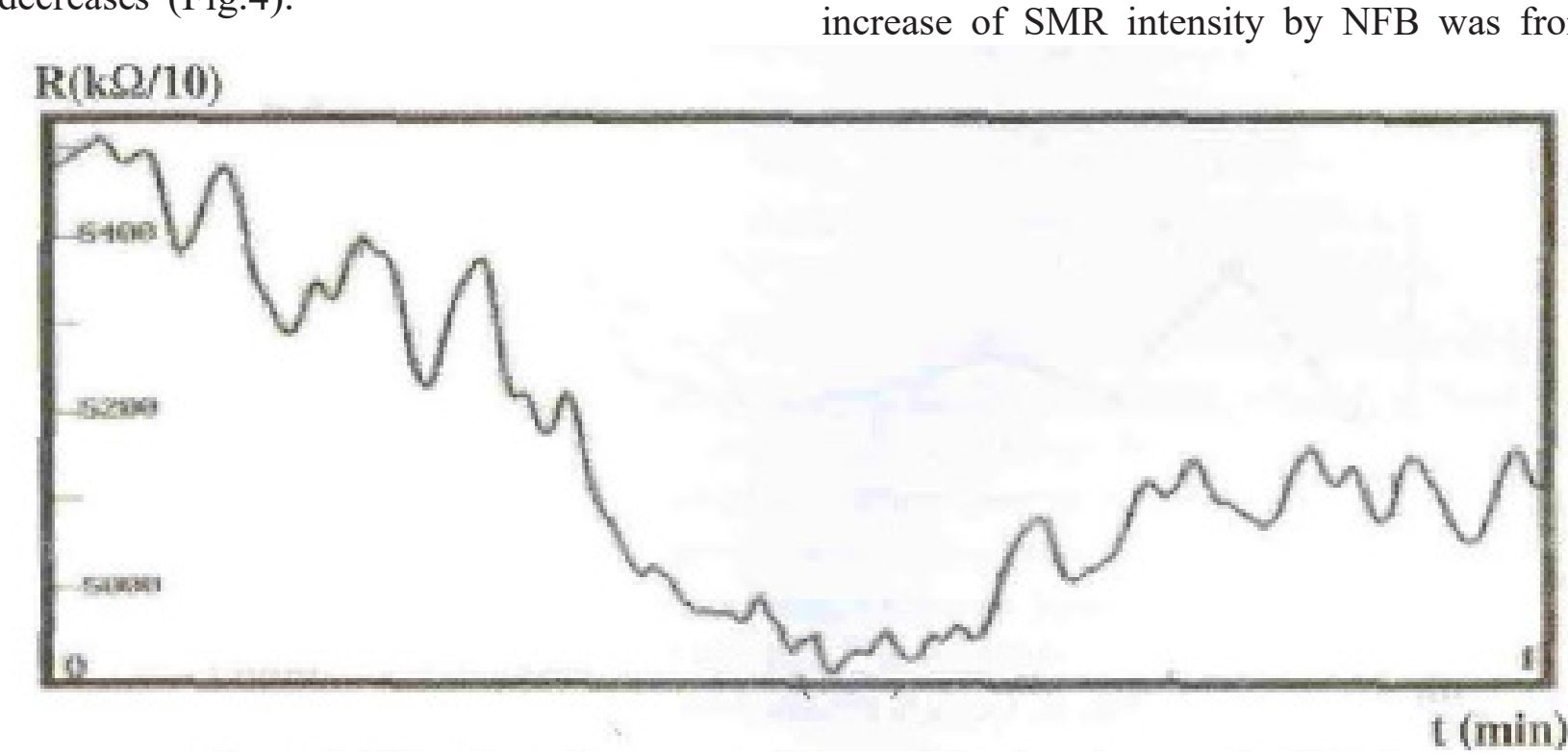

ducing in PTSD children. PTSD is followed by high beta waves $(16-20 \mathrm{~Hz})$ and decreased alpha $(8-12 \mathrm{~Hz})$ and theta $(4-8 \mathrm{~Hz})$ waves. Consequently, standard neurofeedback (NFB) training for post-traumatic stress disorder in adults comprises alpha-theta training. Dealing with children, we introduced SMR (12-16 Hz) training which we consider as more adequate for children. The increase of SMR intensity by NFB was from

Figure 4. Short-term abatement of electrode mal resistance (in $\mathrm{kQ/10}$ )

provoked by recalling a stressful event

In the Figure 5 the summarized results of the change of biofeedback indicators for PTSD are displayed. On the left, results obtained for the whole group from the first and the last session of mean 6.344 to 7.176 (in $\mu \mathrm{V}$ ). So, by EEG-operant conditioning we obtained higher SMR followed by relaxation, motor control, and lower beta (lower arousal). 

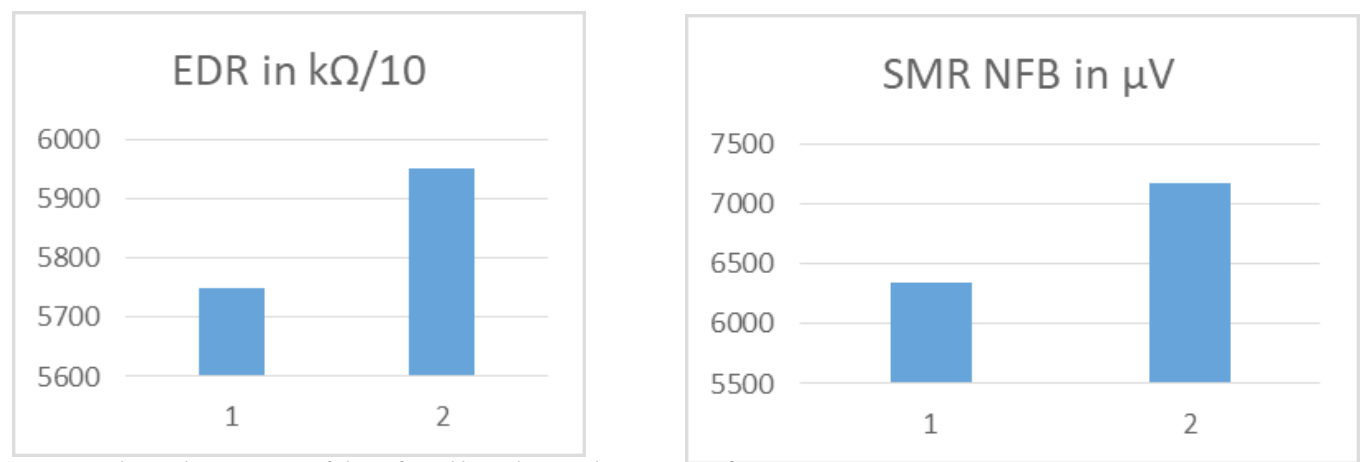

Figure 5. The changes of biofeedback indicators for PTSD

(1-first session; 2- last session)

In essence, neurofeedback is based on monitoring neuronal synchrony (local and global) and shifting the frequency bandwidth by operant conditioning training. An important finding of neurofeedback research and clinics is that global (i.e. long-distance) synchrony represents a physiological mechanism of attention [18]. Our studies of attention deficit disorder in children have also shown a positive correlation between attention and increased synchrony in the high (beta) frequency range [19].

In summary, it was shown that all children manifested PTSD in the early period of life and the clinical presentation was disproportionally greater according to the real level of trauma. This could be correlated to the fact that all of them had an insecure attachment. The social conditions (war, economic poverty) have been the additional background for PTSD. However, PTSD is only a form of anxiety disorder.

In our treatment we used supportive and behaviour-cognitive therapy, combined with EDR and EEG-SMR biofeedback training. The results obtained are very encouraging. The symptoms of PTSD in all children had been eliminated after 20 sessions EDR - EEG biofeedback (one session of 50 minute duration per week).

In brief, two general conclusions can be deduced: (1) The lack of secure attachment, confirmed in all children, contributed to early predisposition to PTSD, related to non-developed ROFC; and (2) Multimodal biofeedback technique appeared to be a good complementary tool for both, assessment and therapy of PTSD in children.

\section{REFERENCES}

1. [1] Mackaud M., Dyregrov Altle., Raundalen M. Traumatic War Experiences and Their Effects on Children, (Eds.) Jensen S. WHO, Zagreb (1994).
2. Begić Drazen, Jokić-Begić Natasa. "Heterogeneity of Posttraumatic Stress Disorder Symptoms in Croatian War Veterans: Retrospective Study". Croat Med J. ; 48, 2 (2007): 133-139.

3. Schneider C. "Early Infant development and Predisposition to Psychophysiologic Disorders". Biofeedback, 4 (1998): 15-17.

4. Manzano Jesus Gil. Les relations precoces parents- enfants et leurs troubles, Med\& Hyg., Suisse (1996).

5. Mazet Philippe. \& Lebovici Serge. Emotions et affects chez le bebe et ses parents. Editions Eshel, Paris (1992)

6. Birch L. L, Marl in D. W, Kramer L., Reyer C.: Mother-child interaction pa t terns and the degree of fatness in chi ldren. J Nutr Educ, 13 (1981): 17-21.

7. Mary D. Salter Ainsworth, Mary C. Blehar, Everett Waters, and Sally Wall. Patterns of attachment, A Psychological Study of the Emmge Situation, Hillsdale, NI, Erlbaurn. (1978)

8. Bowlby John. La perte, P.U.F., 1.vol , Paris (1984).

9. Nada Pop-Jordanova "Rano emocionalno vrzuvanje(Attachment)" Pedijatrija, (1984): 56-66.

10. John Andreassi Human behaviour and Psychological respon se, Lawrence Erl baum Associates, New Jersey, London (2000).

11. Schore Allan. Affect Regulation and the origin ofthe Self: The Neurobiology of Emotional Development, Lawrence Erlbaurn Assoc. (1999)

12. Vinsent Van Hasselt, Hersen Michel. Handbook of Behaviour Therapy and Pharmacotherapy for Children. Allyn \& Bacon (1993).

13. Matsakis Aphrodite. Post-traumatic stress disorder: a complete treat1nent guide. New Harbinger Publications, Oakland (1992).

14. Pynoos R., Nader K. Issues in the Treatment of Post-traumatic Stress in Children and Adolescents (Eds.) Jensen S. WHO, Zagreb. (1994) 
15. Peterson J. M. and Claire E. (2000): Notes on the role of Neurotherapy in the Treatment of Post-Traumatic-Stress Disorder, Biofeedback , 28,3: 10-12.

16. [Scott Fitzgerald. "EEG Biofeedback for Children and Adolescents: A Pediatrician's Perspective". Biofeedback, 26, 3 (1998): 18-20.

17. Evans James \& Abarbanel Andrew. Introduction to quantitative EEG and neurofeedback. San Diego: Academic Press (1999).

18. Fehmi Les. "Synchrony Training", Journal of Neurotherapy, 5, 3 (2001): 69-72.

19. Pop-Jordanova Nada. Biofeedback application for somatoform disorders and attention deficit hyperactivity disorder (ADHD) in children, International Journal of Medicine and Medical Sciences, 1, 2 (2009): 17-22.

\section{(2) Obsessive-compulsive disorder (exec- utive functions)}

Following ICD-10 criteria the OCD belongs to the group of anxiety disorders, but in DSM-5 it was separated from these entities. However, with their characteristic symptoms OCD really belongs to the anxiety syndromes and I will discuss about it in this chapter.

Obsessive-compulsive disorder (OCD) is a mental disorder where people feel the need to check things repeatedly, have certain thoughts repeatedly, or feel they need to perform certain routines repeatedly. People with this disorder are unable to control either their thoughts, or their activities. Common activities include hand-washing, counting of things, and checking to see if a door is locked. Often they take up more than an hour per day. The condition could be associated with other mental problems such as tics, depression, high general anxiety, and there is an increased risk of suicide. In general, such behaviour can disturb the normal functioning of the child. Anxiety is the basic emotional state which pushes the individual to perform obsessive activity in order to relieve the tension, due to the high anxiety level. In this context, in my opinion OCD cannot be separated from other anxiety disorders.

It is estimated that OCD affects $1-3 \%$ of the general population. Following National Comorbidity Survey Replication, lifetime prevalence estimates are as follows: anxiety disorders$28.8 \%$; mood disorders- $20.8 \%$; impulse-control disorders - $24.8 \%$; substance abuse disorders-
$14.6 \%$ etc. Median age of onset is much earlier for anxiety (11 years) and for impulse-control disorders (11 years) compared with the onset of substance abuse (20 years) and mood (30 years) disorders [1].

The cause of OCD is still unknown. However, it appears to be some genetic components with identical twins more often affected than non-identical twins. Risk factors include a history of child abuse or other stress inducing events. Some cases have been documented to occur following severe infections. Males and females are affected equally. Recent volumetric magnetic resonance imaging (MRI) and genotyping of seven polymorphisms in two genes conducted in paediatric OCD patients showed that GRIN2B and SLC1A1 may be associated with regional volumetric alterations in orbit frontal cortex, anterior cingulate cortex and thalamus in children with OCD [2].

One third of adults with OCD developed their symptoms when they were children. Unlike adults, children may not always recognize that their symptoms are senseless or that their compulsions are excessive. They can also involve their family members in their rituals. The recent interest of researchers is to find some measurable neurobiological characteristics in OCD. In this context, the executive functions (EF) are frequently evaluated.

The aim of our research was to inspect EF among children with OCD by using both, psychometric testing and QEEG recording from which we extracted Event Related Potentials (ERPs) on the Go/No Go tasks.

The evaluated sample comprised 20 children (both genders), mean age 14,5 $\pm 2,2$ years, all diagnosed using DSM-IV criteria. Psychological evaluation, as mentioned before, was performed with Child Behaviour Check List, Kohs cubes for assessment of the intellectual capacities, Beck Depression Inventory, The Schedule for Affective Disorders and Schizophrenia for School-Age Children, Stroop Colour Word Test and Wisconsin Card Sorting Test.

Neuropsychological evaluation was performed with the Visual Continuous Performance Test (VCPT) from which the Event Related Potentials (ERP) components were extracted. In the study we included 20 healthy subjects as a control group, which at the time of conducting the study did not have any psychological problems. The control group was corresponding to the gender and age of the experimental group. 
Preliminary, each subject went through detailed interview regarding the course, length and clinical manifestation of the symptoms. Then, a psychometric battery of tests was performed, combined with general scales and scales specific for the EF evaluation.

The results obtained from the psychometric measuring are presented in a form of scores and compared to adequate test norms, adopted by the age and gender of the examinees. Apart from that, we have conducted Student t-test analysis for independent variables to establish if there is a statistical significance between the experimental and the control group.

Results obtained for the CBCL scale for girls and boys have confirmed that there is a significant presence of obsessions (Figure 1 and 2). The results obtained with Kohs cubes for evaluation of the intellectual capacity have shown that this group of children is having superior intelligence (IQ $=112 \pm 11,5$ ). The BDI results are showing that among this group of children with

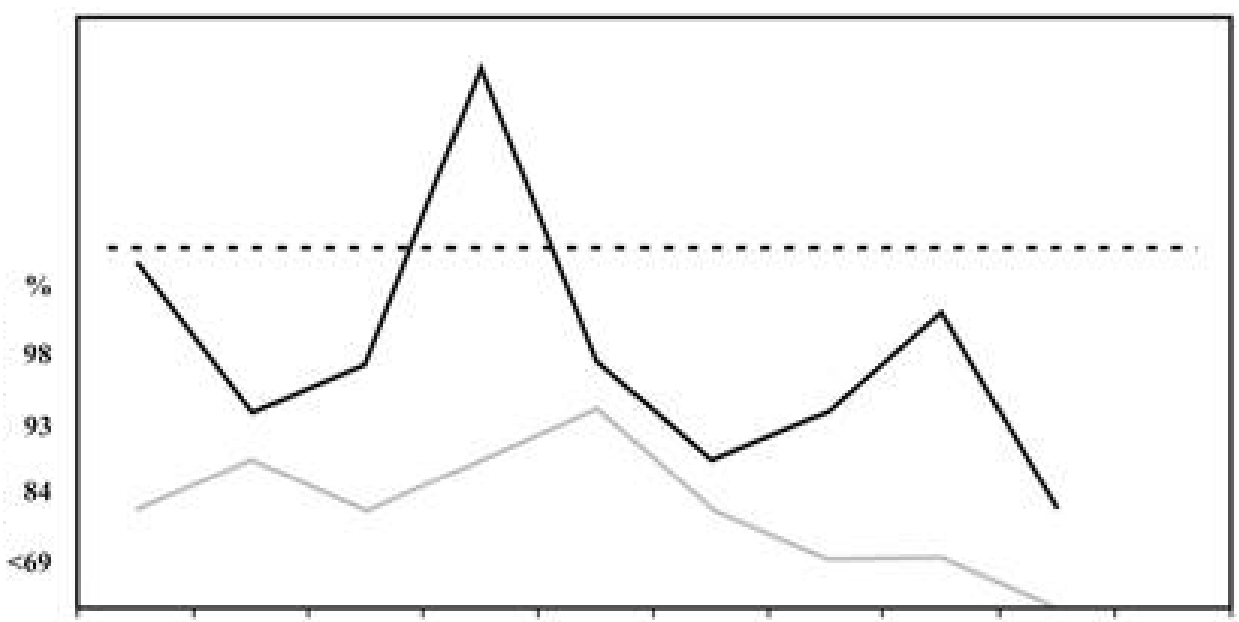

Fig. 1. CBCL profile for OCD boys and control

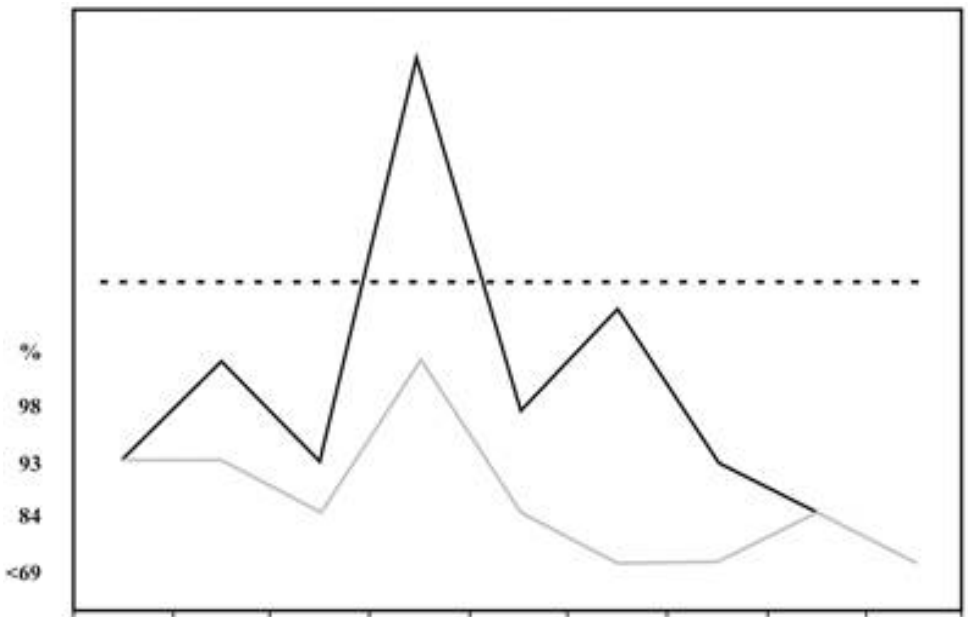

Fig. 2. CBCL for girls with OCD compared with control
OCD there are no signs of clinical depression (BDI=7). The K-SADS shows clear presence of compulsions and obsessions in all subjects (Table 1). In the table we are showing only significant results. The WCST and Stroop Test are showing presence of perseverative errors and mild difficulties in the mental flexibility (Tables 2 and 3 ).

EEG was recorded with Quantitative EEG equipment (Mitsar, Ltd.) amplifier from 19 electrodes, referenced to linked ears (according to the International 10-20 system) with $250 \mathrm{~Hz}$ sampling rate in $0.3-70 \mathrm{~Hz}$ frequency range in the following conditions: eyes opened (EO) -5 minutes, and eyes closed (EC) -5 minutes. The ground electrode was placed between Fpz and Fz. The impedance levels for all electrodes were set at $5 \mathrm{~K} \Omega$. Two stimuli GO/NOGO tasks developed specifically for HBI (Human Brain Institute) database were used. Subjects were instructed to press a button with index finger of their right hand for $\mathrm{GO}$ condition and not to press a button for NOGO condition.

Legend

1. anxiety

2. depression

3. uncommunicating

4. obsessions

5. psychosomatic reactions

6. social withdraw

7. hyperactivity

8. aggressivity

9. delinquency OCD control

Legend

1. anxiety

2. depression

3. uncommunicating

4. obsessions

5. psychosomatic reactions

6. social withdraw

7. hyperactivity

8. aggressivity

9. delinquency

OCD control 
Fig. 3 shows QEEG spectra for a boy with OCD. The low/negative alpha band and significant high beta band especially in the frontal regions due to high anxiety can be seen.

The obtained results showed that at the P3Go (activation) ERP component there are not significant deviations according to the latency and amplitude, while the P3NoGo component (inhibition) is showing diversity for the latency values compared to the norm (Table 5).
Generally, psychometric scales are showing a clear presence of obsessions and compulsions, superior intelligence, no depressive symptoms and presence of perseverative errors and mild difficulties in the mental flexibility. QEEG showed deficit of alpha brain waves and high beta in frontal regions related to anxiety.

Executive functions and self-regulation skills are defined as mental processes that enable

Table 1. K-SADS results for compulsions and obsessions among OCD subjects

\begin{tabular}{l|l|l|l|l|l|l} 
& $\begin{array}{l}\text { parent } \\
\text { compulsions }\end{array}$ & $\begin{array}{l}\text { parent } \\
\text { (FE) }\end{array}$ & $\begin{array}{l}\text { patient } \\
\text { (PE) }\end{array}$ & $\begin{array}{l}\text { patient } \\
\text { (FE) }\end{array}$ & $\begin{array}{l}\text { conclusion } \\
\text { (PE) }\end{array}$ & $\begin{array}{l}\text { conclusion } \\
\text { (FE) } \\
\text { M }\end{array}$ \\
\hline touching & 3 & 1 & 3 & 1 & 3 & 1 \\
\hline washing & 2 & 1 & 3 & 1 & 2,5 & 1 \\
\hline checking & 2 & 1 & 3 & 1 & 2,5 & 1 \\
\hline repeating & 2,9 & 1 & 3 & 1 & 3 & 1 \\
\hline obsessions & & & & & & \\
\hline fear of germs & 3 & 1 & 3 & 1 & 3 & 1 \\
\hline nihilistic thoughts & 3 & 1 & 3 & 1 & 3 & 1
\end{tabular}

PE-present episode; FE-former episode; M-mean; $0=$ no data; $1=$ not present; $2=$ no clinical value;

$3=$ compulsions/obsessions

Table 2. T-value and statistical significance for WCST among children with OCD and the control group

\begin{tabular}{|l|l|l|l|l|l|}
\hline WCST categories & $\begin{array}{l}\text { T-values } \\
\text { OCD }\end{array}$ & $\begin{array}{l}\text { Test } \\
\text { significance }\end{array}$ & $\begin{array}{l}\text { T-values } \\
\text { control }\end{array}$ & $\begin{array}{l}\text { Test } \\
\text { significance }\end{array}$ & $\mathrm{p}$ \\
\hline N categories & 45 & low average & 55 & average & 0,32 \\
\hline N perseverations 2 & 31 & bellow average & 51 & average & 0,000001 \\
\hline N errors & 42 & low average & 50 & average & 0,55 \\
\hline cards total & 43 & low average & 52 & average & 0,16 \\
\hline M categories & 40 & low average & 51 & average & 0,6 \\
\hline
\end{tabular}

*bold means statistical significance

Table 3. T-value and statistical significance of the Stroop Test in OCD and control group

\begin{tabular}{|l|l|l|l|l|l|}
\hline Stroop Test categories & $\begin{array}{l}\text { T-values } \\
\text { OCD }\end{array}$ & $\begin{array}{l}\text { Test } \\
\text { significance }\end{array}$ & $\begin{array}{l}\text { T-values } \\
\text { control }\end{array}$ & $\begin{array}{l}\text { Test } \\
\text { significance }\end{array}$ & $\mathrm{p}$ \\
\hline errors (St) II & 52 & average & 55 & average & 0,1 \\
\hline errors III & 25 & very low & 50 & average & $\mathbf{0 , 0 0 0 0 1}$ \\
\hline errors IIIIII & 44 & low average & 53 & average & 0,33 \\
\hline St III-St II & 25 & very low & 53 & average & $\mathbf{0 , 0 0 0 0 0}$ \\
\hline
\end{tabular}

\footnotetext{
*bold means statistical significance
} 
Table 4. VCPT performance for OCD children

\begin{tabular}{|l|l|l|l|l|}
\hline & OCD & norm & t-test & p \\
\hline omission errors (Go) & 15,4 & 4 & 15,38 & $\mathbf{0 , 0 0 0 0 1}$ \\
\hline commission errors (NoGo) & 2,66 & 1 & 3,22 & $\mathbf{0 , 0 0 1 6}$ \\
\hline RT (ms) Go & 450,26 & 486 & $-2,56$ & $\mathbf{0 , 0 0 0 0 1}$ \\
\hline var RT & 18,48 & 11,7 & 4,4 & $\mathbf{0 , 0 0 0 0 2}$ \\
\hline
\end{tabular}

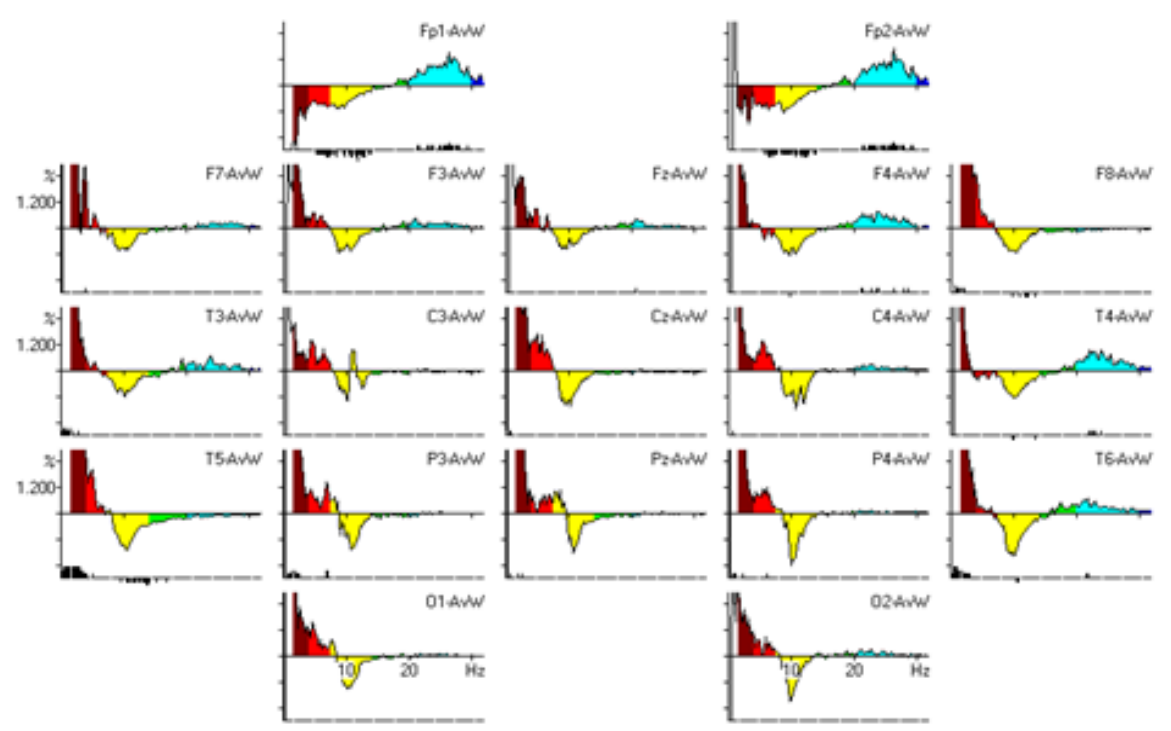

Fig. 3. QEEG spectra for boy with $O C D$

Table 6. $P 3 G$ o and P3NoGo component values for the children with OCD compared with the norm

\begin{tabular}{|l|l|l|l|l|}
\hline & OCD & norm & t-test & $p$ \\
\hline P3Go (ms) & 300,26 & 328,53 & $-1,94$ & 0,061 \\
\hline P3Go (mv) & 9,67 & 8,4 & 1,09 & 0,28 \\
\hline P3NoGo (ms) & 374,66 & 412 & $-4,56$ & $\mathbf{0 , 0 0 0 0 9}$ \\
\hline P3NoGo (mv) & 5,4 & 6,22 & $-1,08$ & 0,28 \\
\hline
\end{tabular}

*bold indicates statistical significance

us to plan, focus attention, remember instructions, and juggle multiple tasks successfully. The brain needs this skill set to filter distractions, prioritize tasks, set and achieve goals, and control impulses. Executive functions (EF) depend mainly on three types of brain function: working memory, mental flexibility, and self-control. These functions are highly interrelated. Each type of skill draws on elements of the others, and the successful application of executive function skills requires them to operate in coordination with each other. Working memory governs the ability to retain and manipulate distinct pieces of information over short periods of time. Mental flexibility helps to sustain or shift attention in response to different demands or to apply different rules in different settings. Self-control enables to set priorities and resist impulsive actions or responses. This system is very important for the functioning of school children in their everyday activities $[3,4,5,6]$.

It is supposed that these functions are not innate; children are born with the potential to develop them. The development of these functions is related mainly to the environmental conditions. If children do not get what they need from their relationships with adults and the conditions in their environments, their skill development can be seriously delayed or impaired. Adverse environments resulting from neglect, abuse, or violence may expose children to toxic stress, which disrupts brain architecture and impairs the development of executive functions. In this context, anxiety may contribute to enable the development of executive functions in children. The localization of the executive functions is in the prefrontal cortex, a part of the human brain which reaches its maturity in the adulthood. 
Different investigations have revealed mixed findings for various executive tasks. Whereas Alarco'n, Libb, and Boll (1994) infer from previous research that OCD is associated with frontal impairments, in a review from Cox $(1997)[9,10]$ it is speculated that comorbid psychotic and depressive symptoms may have induced neuropsychological deficits, which were misattributed to OCD psychopathology. This hypothesis has been confirmed in a study of Moritz et al.[11]. It was found that OCD patients exhibiting elevated depressive scores revealed cognitive deficits, whereas OCD patients with low depressive scores could not be distinguished from controls regarding executive functioning. Our clinical experience confirms that OCD is becoming a common disorder in the childhood; Evaluation of frontal lobe functioning showed that all subjects in this group had high cognitive abilities; Obsessions and compulsions are verified not only clinically, but also trough the CBCL and the K-SADS psychometric instruments; The Stroop Test and WCST are showing difficulties in some aspects of the EF which is within the current OCD theories; The ERP results of our study cannot be understood in the context of executive dysfunction, but in the sense of disturbed normal functioning caused by the high anxiety level. However, our research corresponds with methodology and results of other similar studies for OCD $[12,13,14]$. Generally, there is no significant clinical manifestation of cognitive dysfunction among children with OCD in the early stage of the disorder, but it could be expected the same one to be appearing in the later stages of the disorder.

\section{REFERENCES}

1. Kessler R, Chiu W, Demler O, Walters E. "Prevalence, Severity, and Comorbidity of 12-Month DSM-IV Disorders in the National Comorbidity Survey Replication", Arch Gen Psychiatry; 62 (2005):617-627.

2. Paul Daniel Arnold, Frank P. MacMaster, Margaret A. Richter, Gregory L. Hanna, Tricia Sicard,Eliza Burroughs, Yousha Mirza, Phillip C. Easter, Michelle Rose, James L Kennedy, and David R Rosenberg. "Glutamate receptor gene (GRIN2B) associated with reduced anterior cingulate glutamatergic concentration in paediatric obsessive-compulsive disorder". Psychiatry Res.; 172, 2 (2009): 136-139.
3. Olley A, Malhi G, Sachdev P. "Memory and executive functioning in obsessive-compulsive disorder: A selective review", Journal of Affective Disorders; 104, 1-3 (2007): 15-23.

4. Harvey Norman. "Impaired cognitive set shifting in obsessive compulsive neurosis". IRCS Medical Science 1986; 936-937.

5. Head D, Bolton D, Hymas N. "Deficit in cognitive shifting ability in patients with obsessive-compulsive disorder". Biological Psychiatry; 25 (1989): 929-937.

6. Veale M, Sahakian J, Owen M, Marks M. "Specific cognitive deficits in tests sensitive to frontal lobe dysfunction in obsessive-compulsive disorder". Psychological Medicine ; 26 (1996): 12611269.

7. Purcell R, Maruff P, Kyrios M, Pantelis C. "Cognitive deficits in obsessive-compulsive disorder". Arch Gen Psychiatry; 55, 5 (1998):415-23.

8. Renato Alarcon, J W Libb, T J Boll. "Neuropsychological testing in obsessive-compulsive disorder: A clinical review". Journal of Neuropsychiatry 6, 3 (1994):217-28

9. Rutter Michael, Cox A. "Psychiatric interviewing techniques: I. Methods and measures". Br J Psychiatry.;138 (1981) :273-82.

10. Cox A. Rutter Michel. Diagnostic appraisal and interviewing. In: Child and AdolescentPsychiatry: Modern Approaches, 2nd ed, Rutter Michel, Hersov Lionel. eds, Oxford. England: BlackwellScientific Publications. (1985):233-248

11. Moritz Steffen, Jacob Fink, Franciska Miegel et al (2018). "Obsessive-compulsive disorder is characterized by a lack of adaptive coping rather than an excess of maladaptive coping", Cognitive Therapy and Research DOI: 10.1007/ s10608-018-9902-0

12. Jessica Beer, William G. Kronenberger, Irina Castellanos, Bethany G. Colson, Shirley C. Henning, and David B. Pisoni. "Executive Functioning Skills in Preschool-Age Children With Cochlear Implants". J Speech Lang Hear Res.; 57, 4 (2014): 1521-1534.

13. Tisha J Ornstein, Paul Arnold, Katharina Manassis, Sandra Mendlowitz, Russel Schachar. "Neuropsychological performance in childhood OCD: a preliminary study". Depression and Anxiety 2010; 27: 372-380.

14. Robert Roth, Denise Milovan, Jasinthe Baribeau, Kieron O'Connor. "Neuropsychological Functioning in Early- and Late-Onset Obsessive-Compulsive Disorder". J Neuropsychiatry Clin Neurosci 2005; 17:2. 


\section{(3) Anxiety and stress in children related to dental interventions}

By definition, anxiety and stress are categorized by separate feelings. The stress is associated with frustration and nervousness, where anxiety often comes from a place of fear, unease and worry. Still, despite the differences, many people use the terms interchangeably.

Stress and anxiety share many of the same physical symptoms. Stressful or anxious emotions speed up heart beats, trigger rapid breathing and cause muscle tension. In the occasion when anxiety yields to a panic attack, similarities are much more visible. So, there is definite overlap between stress and anxiety. But, ultimately the two emotions come from two different places. The main differences are in awareness in stress, the sense of helplessness in anxiety, and the period of duration. Stress is generally a temporary experience, while anxiety is a sustained mental health issue. With stress, a person knows what's worrying him/her, but with anxiety it is not the case. The UK National Health Service defines stress as "the feeling of being under too much mental or emotional pressure," while anxiety is "a feeling of unease, worry or fear."

Generally, stress is related to different stimuli which need some responses of the individual. Many years ago Hans Sally (1956) described General Adaptation Syndrome (GAS) as a common bodily reaction to stress. Calls for action differ according the relevance of the cognitive tasks, selected as a challenge or treats. However, it is difficult to separate stress from the actual state of anxiety, which could be an immediate response to the stress.

It is well known that the stress system is among the most important and highly preserved systems in the organism. It is located and functions in both, the central nervous system (CNS) and the periphery. Adequate responsiveness of the stress system to stressors is responsible for attaining homeostasis and achieving a sense of well-being. The adaptive stress response depends not only on the intensity of the stressor, but also on the inherent ability of the stress system to achieve and maintain an appropriate level and duration of activity. The stress response is influenced by both, genetic and developmental factors. In humans the physiological responses to social pressures, information overload, and rapid cultural change resemble those that are produced during physical stress and/or danger and outright threats to survival.

During states of excitement or stress, the body releases adrenaline. Adrenaline is known to cause physical symptoms that accompany anxiety, such as increased heart rate, sweating, and rapid breathing. In many cases having an amount of adrenaline is a good thing. It is helpful when dealing with stressful situations, ensuring alertness and preparation. But for some people the symptoms are difficult or impossible to handle, making it impossible to focus. Anxiety reactions can be generalized from previous experiences to similar situations. Feelings of inadequacy, helplessness, and anticipations of punishment or loss of status and self-esteem are manifestations of anxiety responses.

Anxiety is an emotion that is distressing. Sometimes, it may have no specific cause, unlike fear the cause of which can be seen and dealt with by fighting, or running away. Anxiety is related to personal salience, as a product of personality variables that shapes the perception of "self" and the other world. Anxiety produces the same physiological responses as fear (an increase in sympathetic activity of the ANS), but this level may be maintained for some time if the individual cannot find a way of removing the source of anxiety. The feeling of anxiety is frequently generalized from one situation, or stimulus to another. Anxious people describe themselves as being tense; having some feelings that something terrible will happen. Anxiety is a combination of perceived physiological over-arousal, feelings of worry and dread, self-depreciating thoughts, tension, and somatic symptoms that occur during different situations. It is a physiological condition in which people experience some discomfort, especially during and/or before stressful situations. However, some level of anxiety is normal and often helpful to stay mentally and physically alert. It corresponds to "healthy stress" or eustress, described by Sally. When one experiences too much anxiety, however, it can result in emotional or physical distress, difficulty concentrating, and emotional worry which negatively influence the behaviour. Responses consist of increased heart rate, stress hormone secretion, restlessness, vigilance, and fear of a potentially dangerous environment. Generally, anxiety prepares the body physically, cognitively, and behaviourally to detect and deal with threats to survival. As a result, a person's body begins to hyperventilate in order 
to allow more oxygen to enter the bloodstream, divert blood to muscles, and sweat to cool the skin. We can generalize that the body is in the same time the medium of experience and the instrument of action. Through its actions, we shape and organize our experiences and distinguish our perceptions of the outside world from sensations that arise within the body itself.

Some physiological measures, such as recordings of heart rate, hand temperature, skin response, or brain waves pattern can be used for evaluating the state anxiety or stress, but the practical usefulness of these procedures is limited because measurements, per se, can evoke an increase of the anxiety which complicates the obtained results. The most consistently employed measurements are rating scales determined by the subject or by an observer. The degree to which an anxiety response is developed is based on the probability of bad things happening in the environment and the individual's ability to cope with them.

There is a difference between generalized anxiety disorders (GAD) and state-anxiety. GAD is characterized by anxiety, which results in a person experiencing high levels of stress across a wide range of situations. In contrast, people with state anxiety are anxious, due to high levels of nervousness specific to the concrete situation (e.g. dental intervention).

In their everyday activities dentists must consider not only the total physical condition of their patients, but also their psychological and emotional state. Dental anxiety and fear of dental treatment has been recognized as a source of problems in the management of child dental patients. When treating an anxious child, it is important for the dentist to understand the reason for the child's nervousness. Some research has identified several factors which may have effects on dental anxiety, the most frequent being a painful or unpleasant dental experience, contact with other persons who have previous unpleasant dental experiences or fantasy of dental situations. However, one of the most important factors in explaining children's dental anxiety is their level of general anxiety.

Practically, all dental interventions are stressful and usually are followed by accentuated anxiety, especially in childhood. It has been suggested that some individuals who are fearful or anxious about dental treatment have a constitutional vulnerability to anxiety disorders as ev- idenced by the presence of multiple fears, generalized anxiety or panic disorders. Concerning children population, maternal anxiety is considered to be a major factor affecting the behaviour of young children expecting dental intervention (Johnson, 1968).

The aim of our study was to measure general anxiety in children undergoing dental intervention and to compare it with some personality characteristics, such as psychopathology, extraversion and neuroticism.

The evaluated sample comprises 50 children (31 girls and 19 boys), selected by chance at the University Dental Hospital, Skopje. Mean age for girls was $11.4( \pm 2.4)$ years, and for boys $10.7( \pm 2.6)$ years. Two psychometric instruments were used: General Anxiety Scale for Children (GASC) and Eysenck Personality Questionnaire (EPQ). The obtained results are presented in figures and tables.

The ethnicity of evaluated children is shown on Figure 1. The majority were Macedonian (64\%), Albanian were $28 \%$, while Serbs were only $8 \%$ which corresponds to the general ethnic distribution in our county.

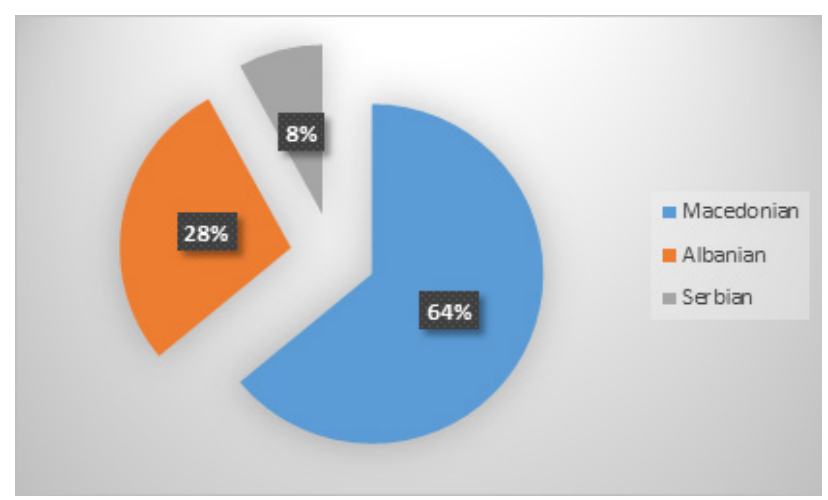

Fig. 1. Ethnicity of evaluated children

Figure 2 shows obtained scores for GASC. It is obvious that all evaluated children showed accentuated anxiety level (obtained scores are over 20). However, girls showed much higher scores for anxiety than boys. 


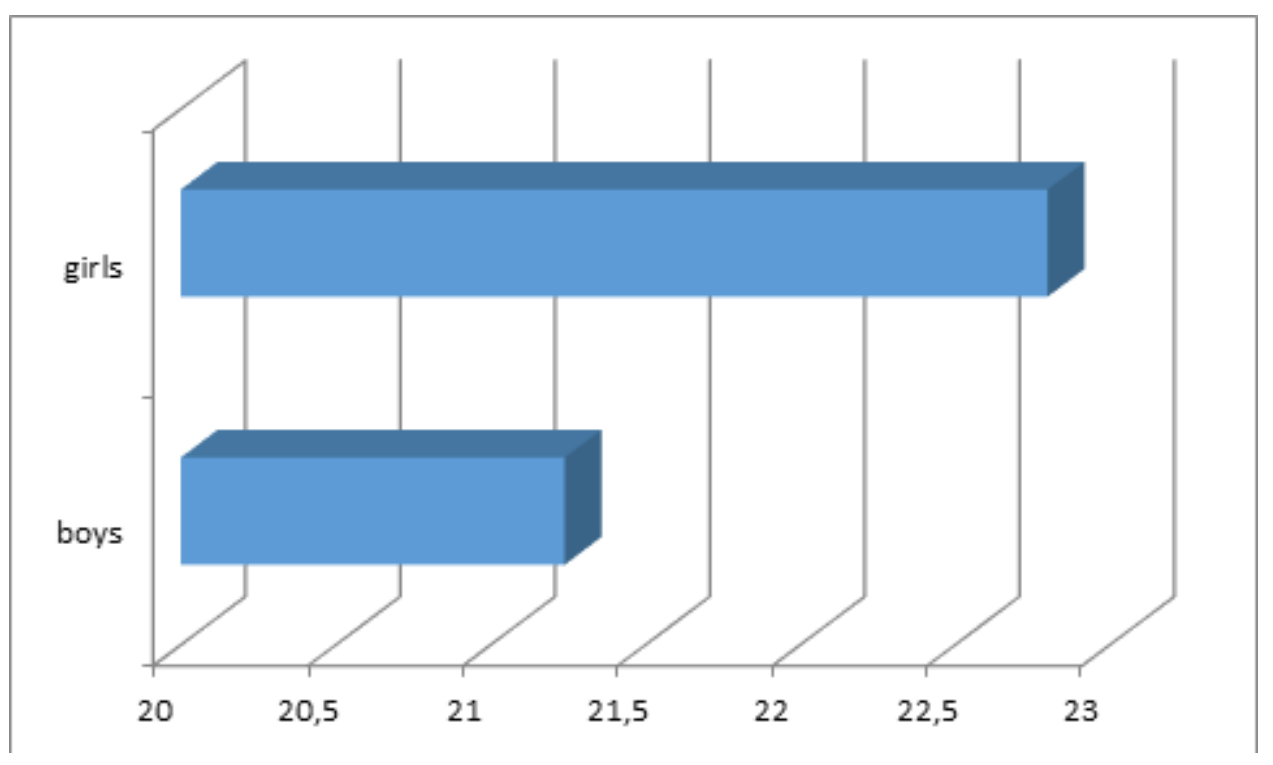

Fig. 2. Obtained scores for Sarason's test: girls manifested higher anxiety than boys

ANOVA calculation shows not significant difference between GASC scores depending on age (Fig. 3). There are some picks on 12 and 13 years which is probably related to the start of puberty.

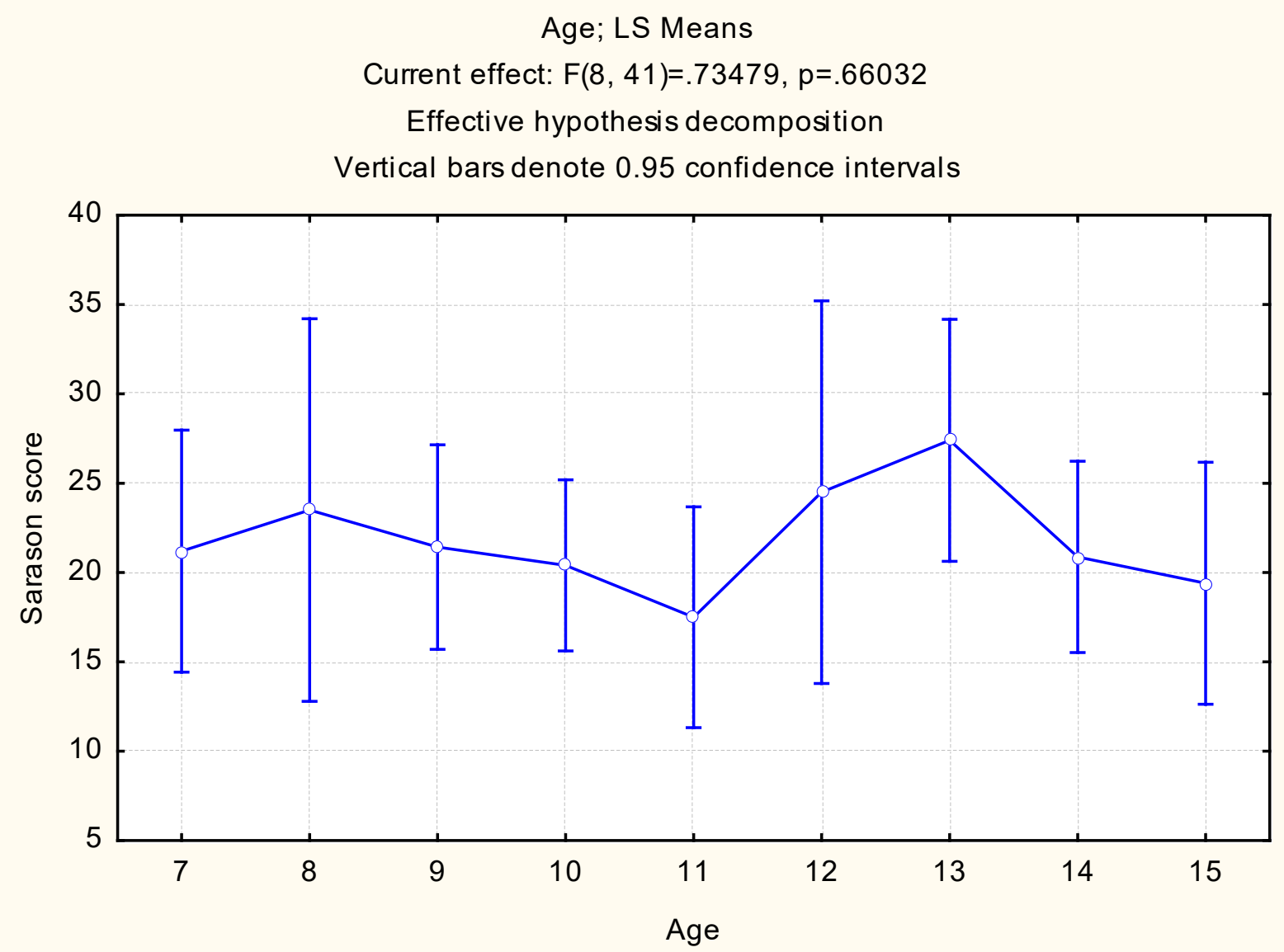

Fig. 3. ANOVA calculation for age related Sarason's scores 
In addition, statistics showed that the correlation between age and obtained scores for GASC ( $\mathrm{r}$ $=0.017$ ) is very small. However, we obtained negative correlation between GASC scores and gender $(\mathrm{r}=-0.28)$. As it has been mentioned above, girls have higher anxiety scores than boys.

Gender; LS Means

Current effect: $F(1,48)=4.3076, p=.04332$

Effective hypothesis decomposition

Vertical bars denote 0.95 confidence intervals

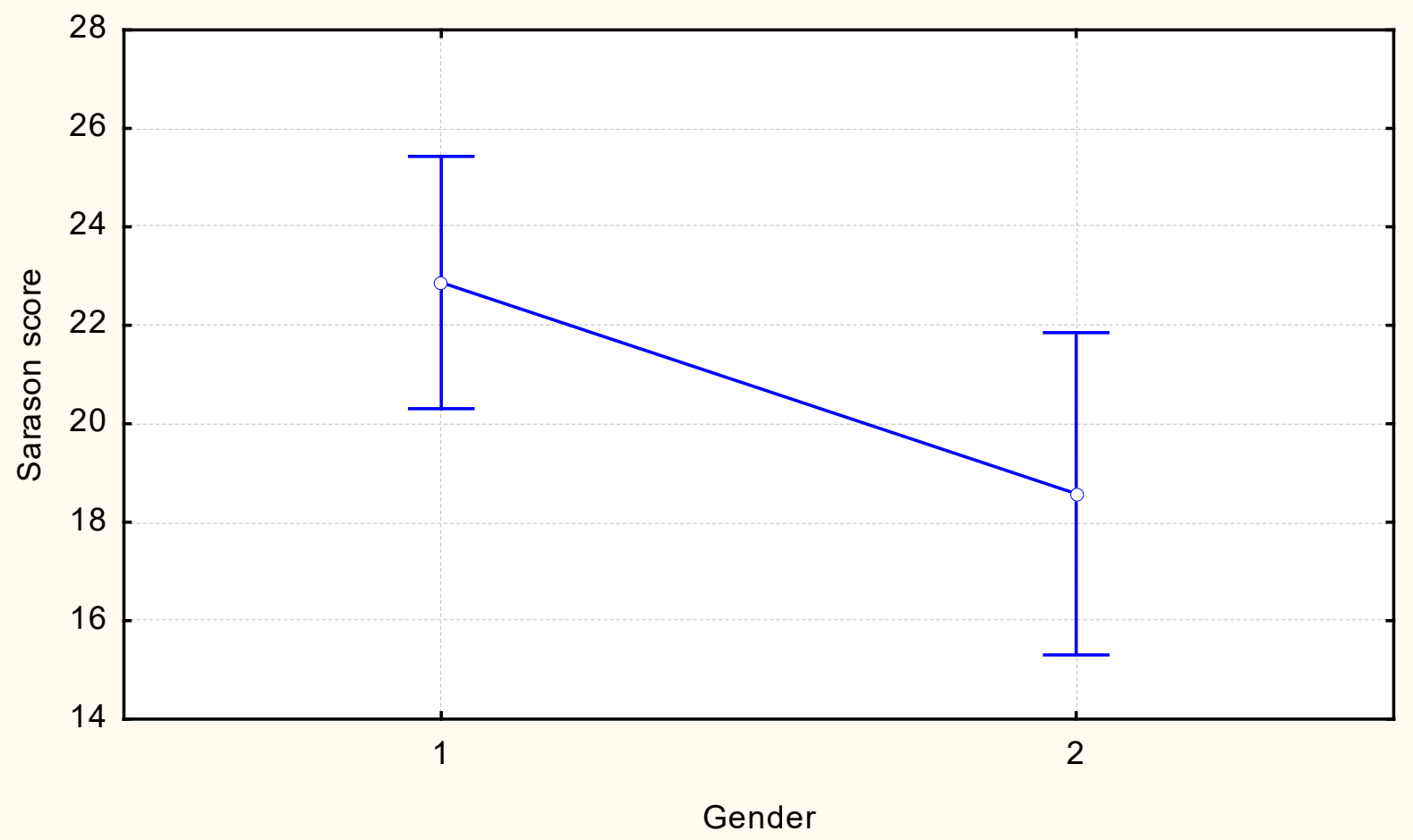

Fig. 4. ANOVA for Sarason's score and gender

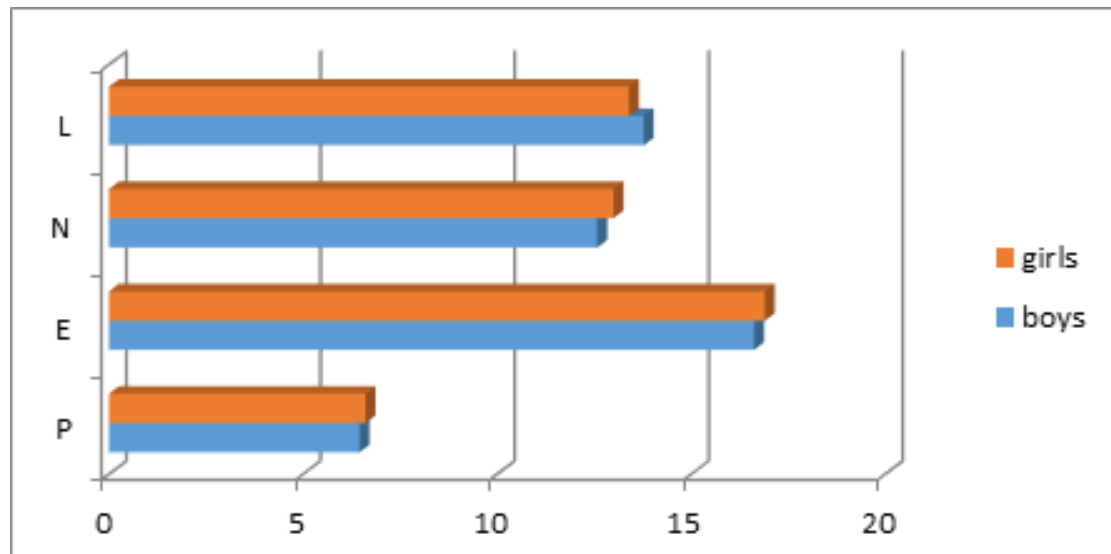

Fig. 5. Obtained scores for EPQ

Distribution of for personality variables obtained by EPQ according to age is presented in Fig. 6. 
Least Squares Means (some means not estimable)

Wilks lambda $=.67799, F(24,109.36)=.53693, p=.95955$

Effective hypothesis decomposition

Vertical bars denote 0.95 confidence intervals

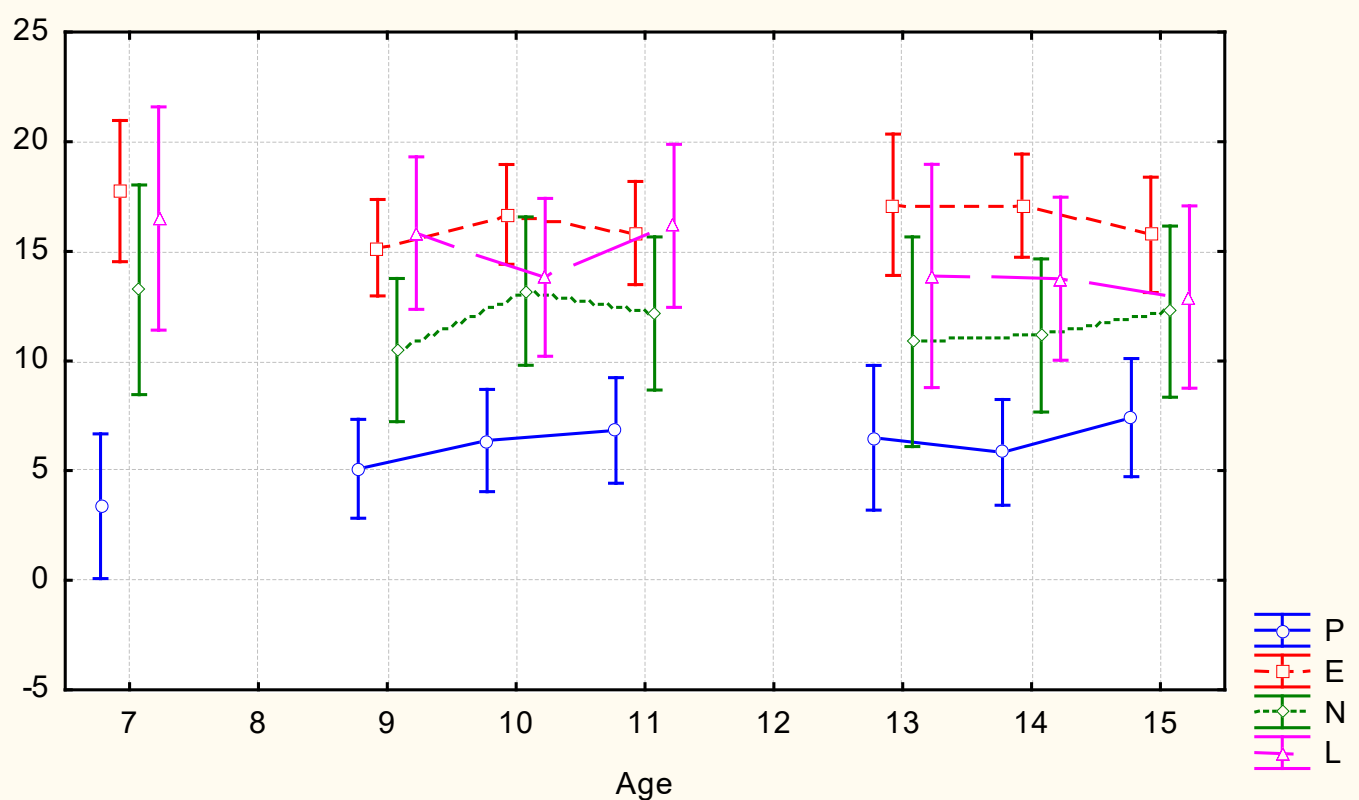

Fig. 6. Distribution of $E P Q$ variables depending on the age

We calculated, in addition, a correlation between GASC scores and scores obtained for EPQ. There is no correlation between GASC scores and P scores $(r=0.056)$, E scores $(r=0.03)$ and $\mathrm{L}$ scores $(\mathrm{r}=0.002)$, but there is a positive correlation between $\mathrm{N}$ scores and GASC $(\mathrm{r}=0.18)$ which seems very logical to us.

Concerning P scores and age we obtained positive correlation (Fig. 7), which means that psychopathological traits rise with the age.

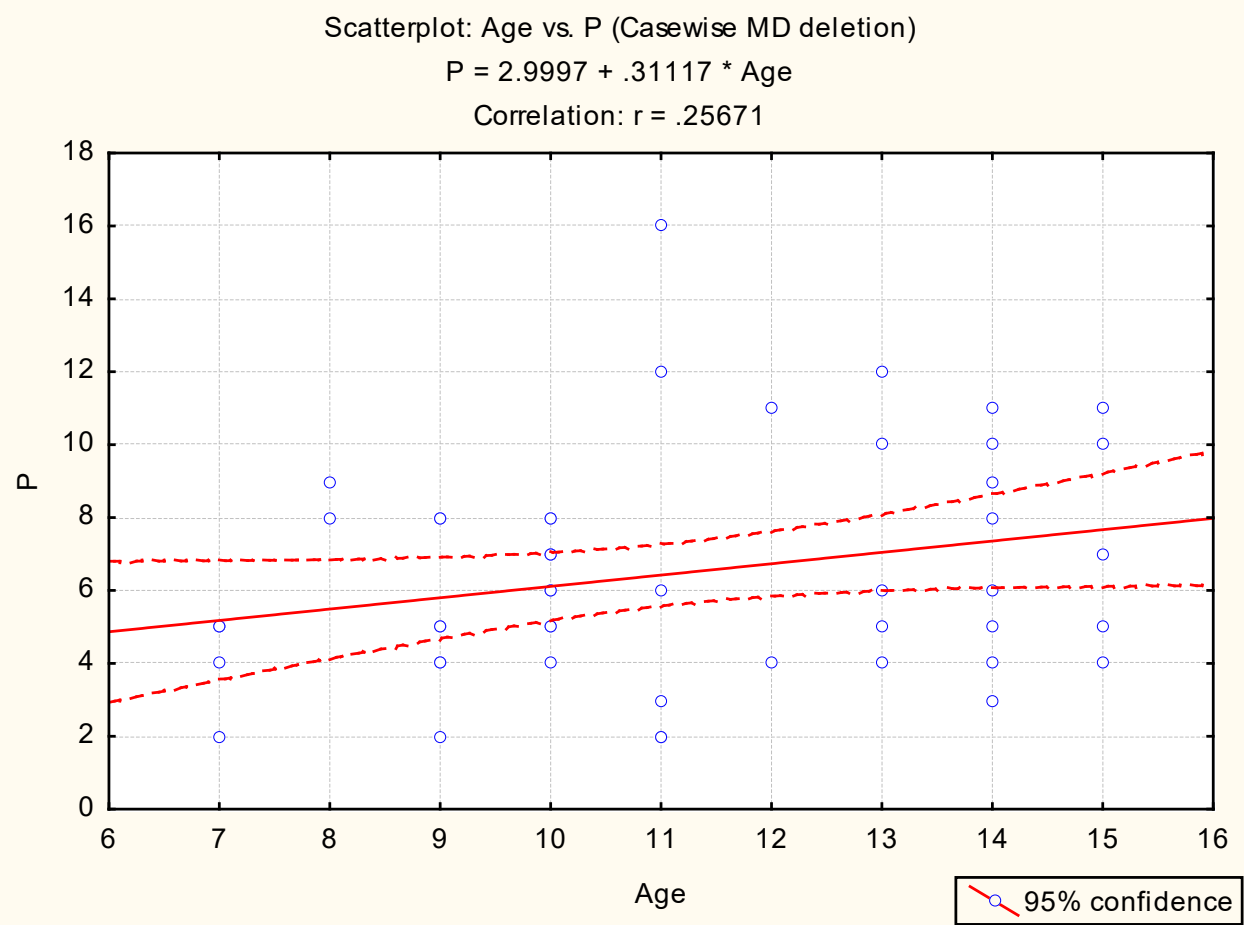

Fig. 7. Correlation between age and P scores on EPQ 
Generally, this study showed accentuated anxiety among children expecting dental intervention; girls were more stressed than boys. There are not differences in personality characteristics between boys and girls. Evaluated children showed low psychopathological traits, moderate extraversion and neuroticism and accentuated non-sincerity in their answers. There is no correlation between personality traits and the level of anxiety, except for the neurotic tendencies.

The relationship between anxiety in dental settings is important for determining the nature of a child's dental fear. Previous studies have revealed that dental anxiety may reflect more general anxiety, rather that fear learned in response to a specific situation.

Our study corresponds to some other similar studies concerning dental anxiety. Locker and al. (2001) in their study concluded that young patients with high level of dental anxiety have high rates of some other psychological disorder, as well. They supposed that the psychological disorder if it is present, was related to the maintenance of dental anxiety over time. Sari and al. (2005) found that trait anxiety of parents and state anxiety for children which were about to start orthodontic treatment were both high. After one year of treatment, the anxiety scores for patients were found to be normal. Fan Xiaoping et al (2005) find that dental anxiety in patients before orthodontic treatment is extensive, and many different factors are closely related to parent's dental anxiety level. They suggested that it is necessary to provide patients with psychological therapy and nursing guidance before intervention.

In a study of Toledano et al. (1995) three psychological variables were determined: anxiety, personality and intelligence. Researchers found no significant relationship between levels of dental anxiety and age; anxiety was higher among girls. In addition, they found that children with high intelligence quotients showed less dental anxiety at their first dental visit. Also, they did not find a relationship between children's anxiety and their own personality variables. The results obtained in our study completely correspond to the mentioned ones. In the study of Peretz and Efrat (2000) it was concluded that individual personality traits may be the final factor to indicate those who will eventually develop higher dental anxiety, and those who will not. The difference could be also in the conditioning process and learned responses (male and female education) that these individuals have experienced in life.

An extensive Danish study (1995) investigated dental fear and behaviour management problems in children's population. The results showed that age, general emotional status and maternal dental anxiety were identified as concomitant factors in the development of dental fear. Experiences of pain during dental treatment increased the risk of developing dental fear and behavioural problems. In a Scottish study (1992) the prevalence of dental anxiety was found to be $7.1 \%$ girls also had higher levels of anxiety than boys. They found an association between anxiety and lower social class level (defined by father's occupation). Two factors were pointed as useful predictors of high dental anxiety: the length of time since the last visit to the dentist and the number of people known by the child to be afraid of going to the dentist. In a study of Taani (2002), results showed that dental anxiety in Jordan was more pronounced in low and moderate social level of children's families. Similarly, Corkey and Freeman (1994) demonstrated that the child's ability to cope with dental treatment was based upon his/her degree of psychological development together with the mother's fear of dental treatment. It is pointed out that the role of the mother plays a central part, influencing on the one hand the child's degree of psychological development and on the other the child's ability to cope with dental treatment.

In a study of Raadal et al. (1995) dental anxiety was found to be higher in boys, but relationship between anxiety and Child Behaviour Checklist (CBCL) scores was not demonstrated. In a study of Blomqvist et al. (2006) it was found that children with ADHD have more behaviour management problems, but do not exhibit a higher degree of dental anxiety than controls.

The age of onset of dental anxiety was studied in a study of Locker et al. (1999). Findings showed that negative dental experiences were predictive for dental fear, regardless of age of onset. A family history of dental anxiety (as an exogenous etiological category) was predictive of child-onset anxiety. In 5-year-old children living in North West England dental anxiety was recognized as a common condition and it was closely associated with a symptomatic irregular attendance pattern, a history of extraction and having a dentally anxious parent. 
Dental anxiety may lead to neglect of dental care, both among children and adults and represents a problem to patients and dentists alike. Previous dental experience has been cited as a cause of dental anxiety. There are reports of decreasing levels of dental anxiety with increasing age among children. Closely related to previous dental treatment may be the expectation of pain. It is broadly accepted that personality characteristics intervene between stimuli and response, modifying the effects of the stimuli. Neverlien and Backer (1991) showed that both self-reported dental anxiety and optimism-pessimism were unique contributors to prediction of behavioural rating of dental anxiety.

In addition, anxiety has been identified as being one of the major factors that have an impact on dental pain. However, expected pain is less intense than unexpected one. Furthermore, anxious patients are more neurotic and unstable, less decisive, have a lower self-esteem, are less inclined to act. There is conclusive evidence that patients with acute dental pain do benefit from psychological intervention (Schuurs et al. 1987).

The management of dental anxiety in children comprises several issues: early education about the need of dental care, elimination of pain, psychological support, as well as some techniques like relaxation, and peripheral biofeedback. Support of the mother (family) is the most important for child behaviour management.

In summary,

This study confirms the presence of high anxiety level (evaluated with GASC) among children undergoing dental intervention.

It was confirmed that there are differences in anxiety scores between girls and boys, girls manifesting higher anxiety.

Personality characteristics (evaluated with EPQ) showed low psychopathological traits, moderate extraversion and neuroticism, but accentuated insincerity (evaluated with L scale). L scales are lower with increasing age, but $\mathrm{P}$ scores are rising with age, which could be related to the puberty.

There is no found correlation between personality traits (obtained scores for EPQ) and anxiety, except for the neuroticism, which is positively correlated with the level of anxiety.

In the management of dental anxiety some response measures (psychological support, biofeedback, and relaxation techniques) are recommended.

\section{REFERENCES}

1. Selye Hans. The stress of life. New York: McGraw Hill.(1956)

2. Johnson Ronald, Dewitt Baldwin. "Relationship of maternal anxiety to the behaviour of young children undergoing dental extraction". Journal of dental Research; 47, 5 (1968): 801-805.

3. Locker D, Poulton R, Thomson WM. "Psychological disorders and dental anxiety in young adult population '. Community Dent Oral Epidemiol; 29, 6 (2001): 456-63.

4. Sari Z, Uysal T, Karaman A.I, Sargin N, Ure O. "Does orthodontic treatment affect patient's and parent's anxiety levels?"Eur J Orthod; 27, 2(2005): 155-159.

5. Fan Xiaoping et al. "The prevalence of dental anxiety before orthodontic treatment". Journal of Chongqing Medical University, 2005-05.

6. Toledano M, Osorio R, Aguilera F.S, Pegalajar J. "Children's dental anxiety: influence of personality and intelligence factors". International Journal of Paediatric Dentistry, 5 (1995): 23-28.

7. Wogelius P, Poulsen S, Toft Sorensen H. "Prevalence of dental anxiety and behavior management problems among six to eight years old Danish children". Acta Odontologica Scandinavica; 61, 3 (2003): 178-183.

8. Bedi Raman, Sutcliffe P, Donnan Peter, McConnachie J. "The prevalence of dental anxiety in a group of 13- and 14-year-old Scottish children". International Journal of Paediatric Dentistry; 2 (1992): 17-24.

9. Quteish Taani. "Dental attendance and anxiety among public and private school children in Jordan".52, 1 (2002): 25-29.

10. Corkey B, Freeman R. "Predictors of dental anxiety in six-year-old children: iding from a pilot study". ASDC J Dent Child; 61,4 (1994): 267-71.

11. Raadal Magne, Milgrom Peter, Weinstein Philip, Mancl LLoid, Cauce AnaMarry. "The

prevalence of dental anxiety in children from low-income families and its relationship to personality traits". Journal of Dental Research; 74, 8 (1995): 1439-1443.

12. My Blomqvist, Kirsten Holmberg, Elisabeth Fernell, Ulla Ek, Göran Dahllöf "Oral health, dental anxiety, and behaviour management problems in children with attention deficit hyperactivity disorder". European Journal of Oral Sciences; 114, 5 (2006): 385-390.

13. Neverlien Per Otto, Backer Johnsen T. "Optimism-pessimism dimension and dental anxiety in children aged 10-12 years". Community Dent Oral Epidemiol;19, 19(1991): 342-6. 
14. Albert H. B. Schuurs, Hugo J. Duivenvoorden,Peter C. Makkes,Sijo K. Thoden van Velzen,Frans Verhage. "Personality traits of patients suffering extreme dental anxiety". Community Dentistry and Oral Epidemiology, 16, 1 (1988):38-41.

\section{(4) MMPI profiles for general anxiety and attack panic syndrome in young people}

For evaluation of the personality different psychometric tests are currently used (e.g. Eysenck Personality Questionnaire, Big- five, 16Type Jungian Personality Test etc.), but it is obvious that in the clinical practice, the most used personality test worldwide is MMPI (Minnesota Multiphasic Personality Inventory), which gives much more information about personality than other tests. Searching in PubMed about 400 articles could be found in which MMPI was used in the evaluation of patients with different diseases. The scientific literature demonstrates that personality traits are associated with the individual's adaptation to chronic diseases, but they can also be an important factor in the aetiology and prognosis of many physical and mental illnesses $[1,2,3,4]$. For example, in the study of Mucci et all. 2014, it was shown that some personality traits, especially neuroticism, psychasthenia, and schizoid aspects, may be associated with tinnitus perception and with the annoyance, due to this symptom. In this context, we used the MMPI for personality evaluation in patients with general anxiety and attack panic syndrome.

The original MMPI, first published by the University of Minnesota Press in 1943, was replaced by an updated version, the MMPI-2, in 1989. The MMPI-201 used in this research, is the oldest form of the test standardized in ex-Yugoslavia and until now it has been used more frequently in this region. MMPI-201 contains ten clinical scales: Scale 1- Hypochondriasis scale, which measures a person's perception and preoccupation with their health and health issues; Scale 2- Depression scale measures a person's depressive symptoms level; Scale 3- Hysteria scale measures the emotionality of a person; Scale 4- Psychopathic Deviate scale measures a person's need for control or their rebellion against control; Scale 5- Paranoia scale measures a person's inability to trust; Scale 6- Psychasthenia scale measures a person's anxiety levels and tendencies for somatization and obsession; Scale 7- Schizophrenia scale measures a person's unusual/odd cognitive, perceptual, and emotional experiences, and Scale 10- Mania scale measures a person's energy, euphoria or hyperactivity.

Three additional scales $\mathrm{L}, \mathrm{F}$ and $\mathrm{K}$ are validity scales and measure the readiness of the responders to this kind of examination. L scale refers to rigidity or naiveté of responder's approach to the test material; $\mathrm{F}$ scale refers to confused thinking/ lack of understanding the questions or malingering; K scale refers to responses chosen to be socially acceptable.

Raw scores on the scales are transformed into a standardized metric known as T-scores (Mean or Average equals 50, Standard Deviation equals 10), making interpretation easier for clinicians. Before analysis of clinical scales, some criteria should be satisfied: L and $\mathrm{K}$ scales must be with the score $\leq 70$ and $\mathrm{F}$ scale $\leq 80$. A significant advantage of the MMPI over other self-report and observer rating scales is that it provides valid and reliable estimates of response bias.

Groups of scales are examined at the same time, for example, the validity scales $(\mathrm{L}, \mathrm{F}, \mathrm{K})$, the neurotic triad (Hs, D, Hy), and the psychotic tet$\operatorname{rad}(\mathrm{Pa}, \mathrm{Pt}, \mathrm{Sc}, \mathrm{Ma})$. It is argued that the overall elevation of the clinical scales presents a reasonably accurate presentation of the degree of distress the client is experiencing (Greene, 2000).

In this research Minnesota Multiphasic Personality Inventory (MMPI) was used for the assessment of the personality characteristics of a group with General Anxiety Disorder comprising 20 young females and 15 males, mean age $25,7 \pm$ 5,35 years, as well as a group of 15 patients with Panic attack syndrome, aged 19,3 $\pm 4,9$ years. For testing with MMPI the needed conditions are normal/above normal intelligence, reading ability and the ability to understand the questions. In this line, only the age over 12 years is suitable for testing. For comparing obtained results we used two control groups of people: The first control group comprises students recruited from the Computer science faculty, 18 males and 15 girls, mean age 20.5 (SD 2.3) years. They are without any health problems (somatic or neuropsychiatric). Obtained MMPI profiles are presented in Figure 1. As can be seen, all control and clinical scales have obtained scores in normal range. In girls we obtained pick on Pa scale but in "normal" range which can be a sign of hypersensitivity. The second control group comprised healthy adults selected by chance, comprising 15 males and 15 females, mean age 44.16 (SD 10.9) years. Obtained MMPI-201 pro- 
files are shown in Figure 2. There is no significant gender difference obtained with ANOVA testing in both control groups.
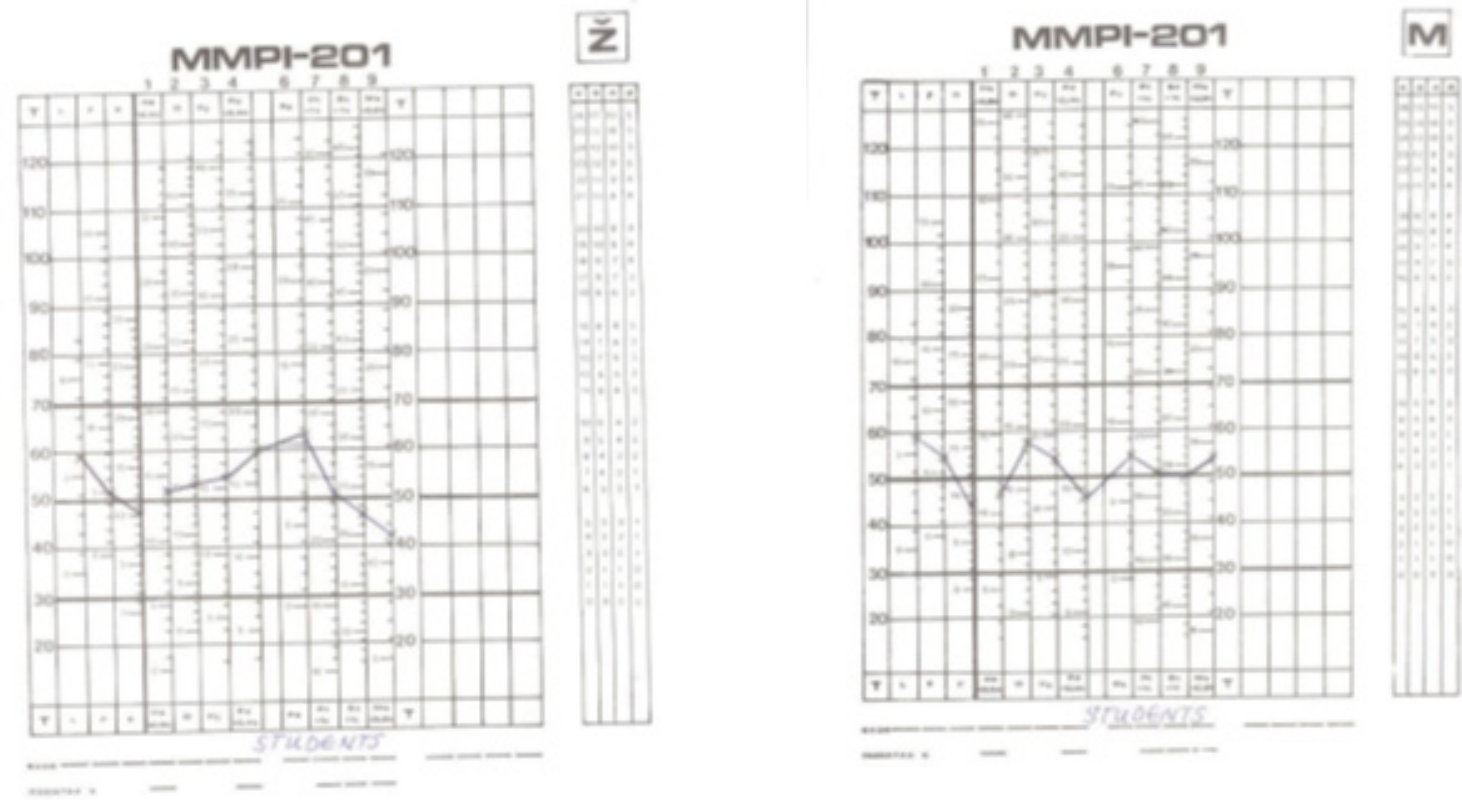

Fig. 1. MMPI profiles for healthy students
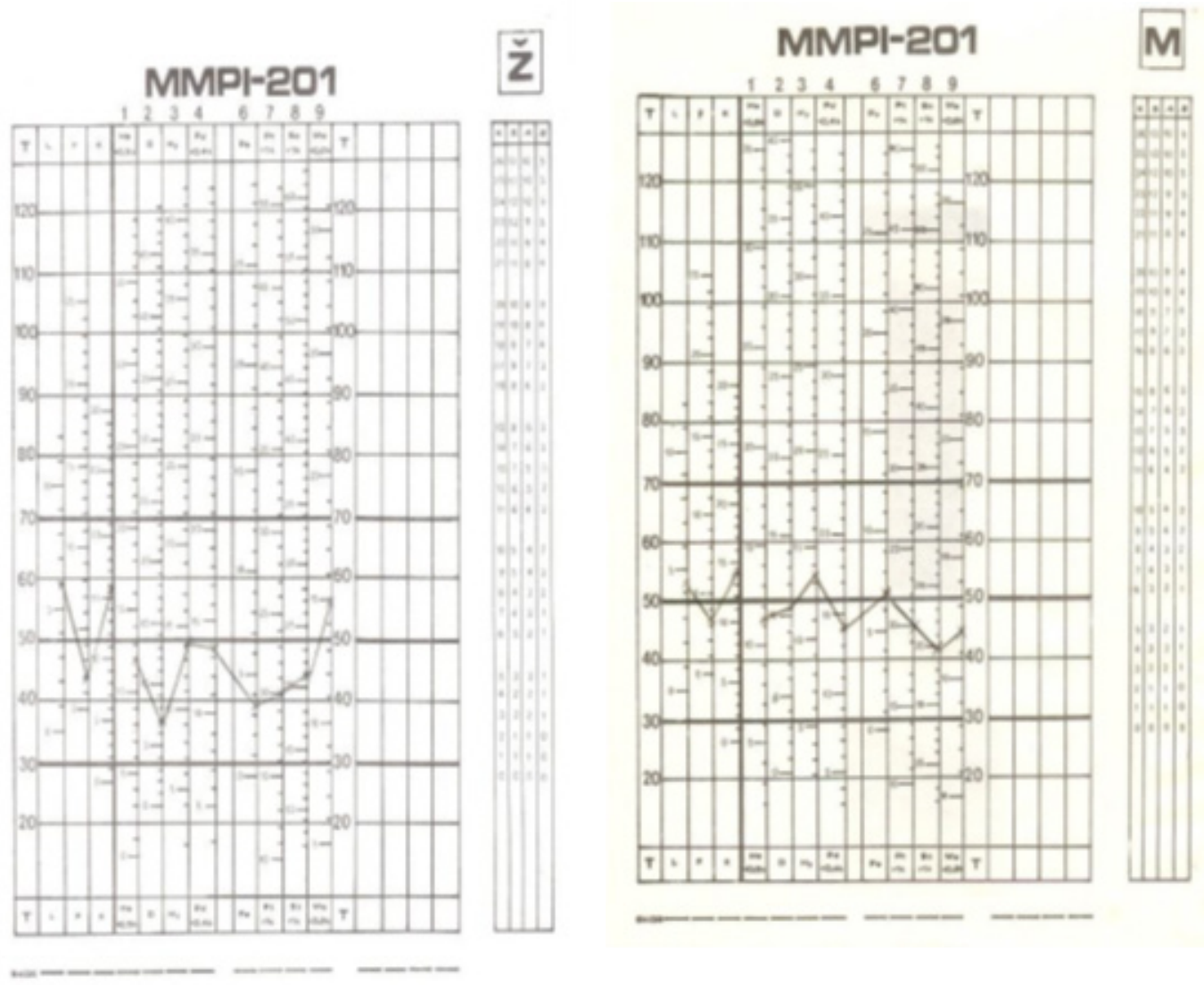

Fig. 2. MMPI profiles for healthy adults 
In the Figure 3 obtained profiles for a group of patients with general anxiety are presented.

As mentioned before, the group comprised 20 females and 15 males diagnosed with general anxiety, mean age 25.7 (SD 5.35) years. The diagnosis was established by a clinical psychologist according to the DSM-IV criteria. Testing is made before any treatment. As can be seen females showed only Hy peak, but in the normal range. However, statistics confirmed significant difference between scores in anxiety group and control $(t=2,25164 ; \mathrm{p}=0,038749)$. Males showed Hs-Hy-Pt peaks with higher (pathological) scores, related to hypersensitivity of the autonomic nervous system, as well as with manifested anxiety. Calculation confirmed significant difference between control and anxiety group in men $(\mathrm{t}=15.13, \mathrm{p}=0.000)$.
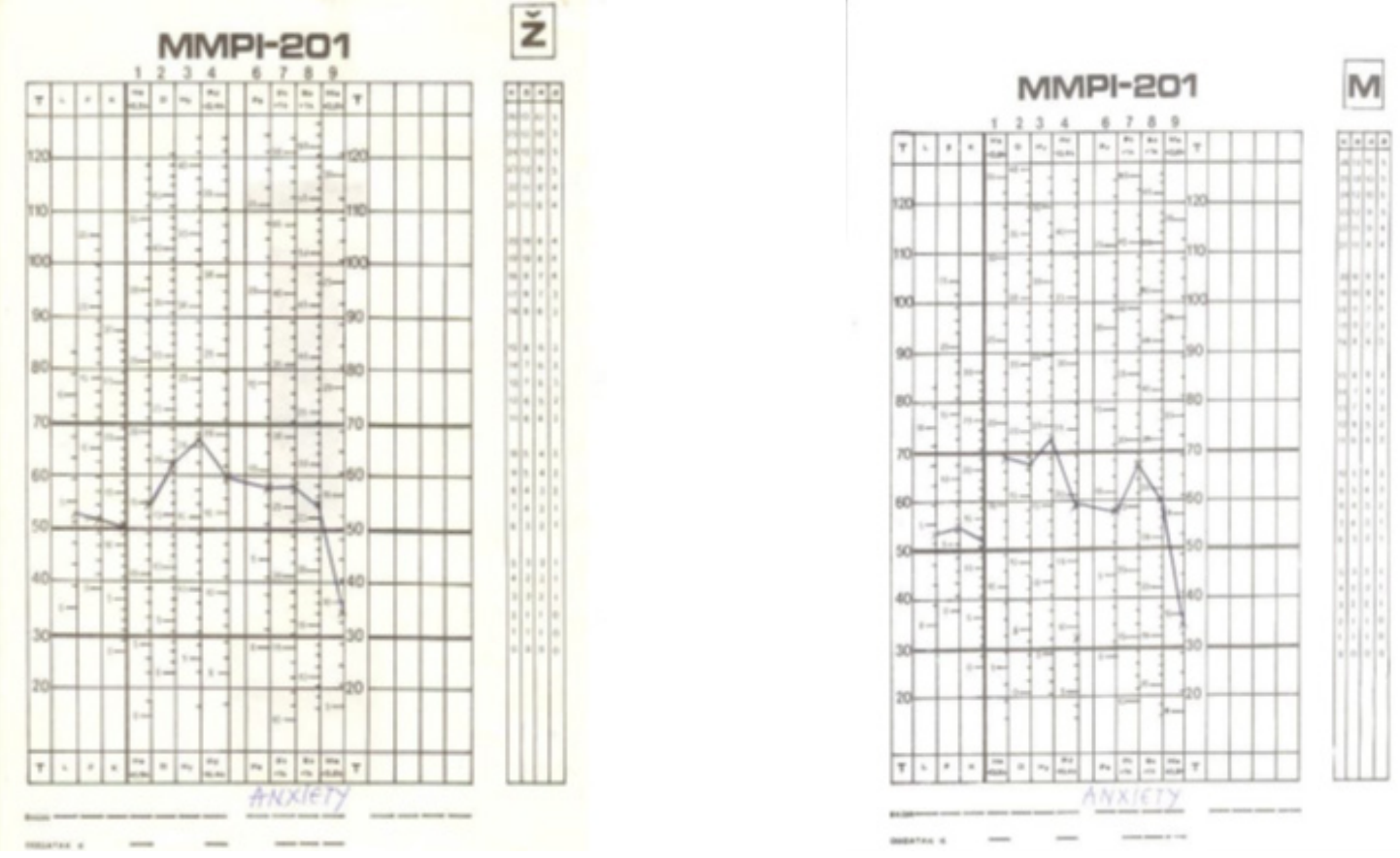

Fig. 3. MMPI profiles for healthy students

Obtained profiles for patients with attack panic syndrome comprising ten males and five females, mean age 19.3 (SD 4.9) years are shown on Fig. 4. Control scales for females showed typical V form (scales 1 and 3) related to converse tendencies. Pathological profile is obtained in males, with Hy-Sc peaks; this profile corresponds to persons with regressive characteristics, emotionally instable and with accentuated social withdraw. Females showed peaks on Pt-Sc scales, but in normal ranges.
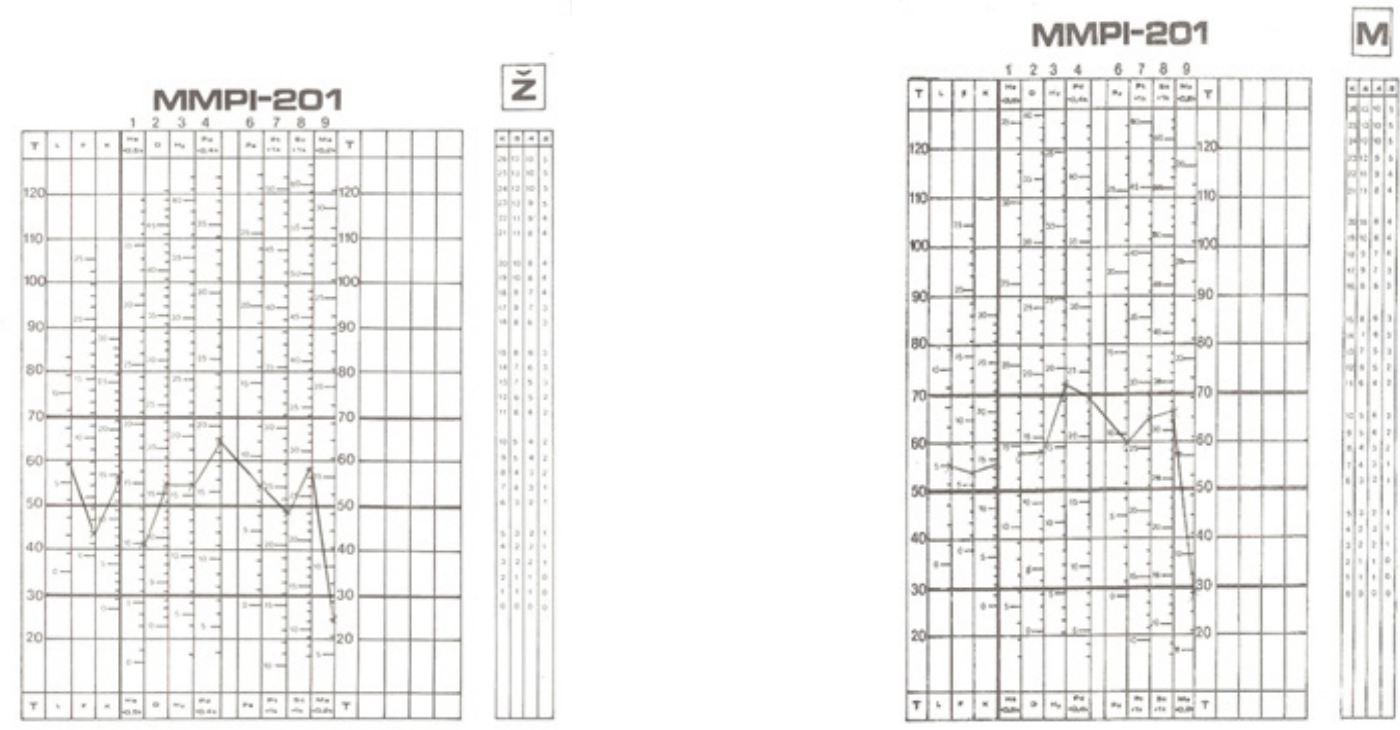

Fig. 4. Profile obtained for patients with panic attack syndrome 
The Minnesota Multiphasic Personality Inventory is a broadband measure of psychopathology and personality that has a long tradition in assessment of medical patients. The MMPI have been extensively used for both, the assessment of the impact of medical illness on the emotional and psychological well-being of the individual, but also to predict compliance with treatment and suitability for some planed interventions.

A major advantage to the use of the MMPI in medical settings is the utility of the instrument in identification of co-morbid psychiatric conditions. Scales associated with general distress and maladjustment, as well as scales associated with symptoms delineating specific conditions such as depression, anxiety, and psychosis are contained within the inventory. Both anxiety and thought disorder will also impact a patient's ability to participate in rehabilitation or comply with treatment recommendations and the assessment of those conditions through use of the MMPI is valuable in treatment planning with the medically ill patient.

As a result of different studies, it can be concluded that the MMPI profile is very specific and sensitive for identifying personality structure and psychopathology in different people and in different health conditions. As can be concluded for our research, MMPI profiles correspond to the diagnosis of examined participants. MMPI201 was applied for assessment of the patients with anorexia nervosa, for patients undergoing haemodialysis, with chronic disease [7-12].

In general, the MMPI helps us to obtain a global, factual picture from the self-assessment of the patient, explained in a psycho-technical language. For easier distinction between the "normal" and the "abnormal," the sociopathic personality and psychiatric one, as well as between psychotic and neurotic personalities, Goldberg (1968) has proposed a different formula that facilitates interpretation. For example, the distinction between psychotic and neurotic profiles is based on calculating the formula $(\mathrm{L}+\mathrm{Pa}+\mathrm{Sc}-\mathrm{Hy}-\mathrm{Pt})$ with a critical score of $45 . \mathrm{In}$ addition, MMPI scores allow some additional indexes to be calculated for the assessment of control mechanisms, aggressiveness, anxiety, or psychosomatics.

The IR (internalization ratio) is calculated with the following formula: $\mathrm{IR}=\mathrm{Hs}+\mathrm{D}=\mathrm{Pt} /$ $\mathrm{Hy}+\mathrm{Pd}+\mathrm{Ma}$ [7]. Expressive-repressive index ER
$=(\mathrm{L}+\mathrm{K}+\mathrm{Hy})-(\mathrm{Pd}+\mathrm{Ma}) ;$ Frustration tolerance $\mathrm{FT}=\mathrm{Pd}+\mathrm{Ma} / \mathrm{D}+\mathrm{HY}$; active hostility $\mathrm{AHI}=\mathrm{Pd}+-$ $\mathrm{Ma}$, while passive aggression $\mathrm{PAI}=(\mathrm{Hy}+100)$ $-(\mathrm{Pd}+2 \mathrm{~Pa})$.

The anxiety index is calculated using the formula: $\mathrm{AI}=1.33 \mathrm{D}+1.00 \mathrm{Pt}-0.66 \mathrm{Hs}-0.66 \mathrm{Hy}$. With these additional indexes, the interpretation of the resulting MMPI scores is more enlarged and gives an additional security.

AD was 15, 72 for females and 6, 84 for men, as expected. This results correlate with the diagnosis of anxiety. For panic attack group AI for females was very high (i.e. 28, 12), and for males 19,84 . It also corresponds with high anxiety level. For manifested anxiety, it is possible to select some items from MMPI questionnaire and included them as "Taylor scale" which is clinically approved as valid.

Interpretation of the MMPI profile also involves configural analysis of subsets of the validity and clinical scales. Groups of scales are examined at the same time, for example, the validity scales (L, F, K), the neurotic triad (Hs, D, $\mathrm{Hy})$, and the psychotic tetrad ( $\mathrm{Pa}, \mathrm{Pt}, \mathrm{Sc}, \mathrm{Ma})$. It is argued that the overall elevation of the clinical scales presents a reasonably accurate presentation of the degree of distress the client is experiencing (Greene, 2000). Group's profile could be used in clinical practice for planning treatment and to suppose the prognosis of the illness.

\section{REFERENCES}

1. Butcher James, Williams Carolline. "Personality assessment with the mmpi-2: historical roots, international adaptations, and current challenges". Applied Psychology: Health and Well-Being 1, 1 (2009): 105-135.

2. Bosch Peggy, Van Luijtelaar G, Van Den Noort Maurits, Schenkwald J, Kueppenbender N, Lim Sabine, Egger J, Coenen Anton. "The MMPI-2 in chronic psychiatric illness". Scand J Psychol.;55, 5(2014):513-9

3. Robinson M, Greene A, Michael E, Geisser M. "Specificity of MMPI cluster types to chronic illness". Psychology \& Health; 8, 4 (1993):285294

4. Arbisi Paul, Butcher James. "Relationship between personality and health symptoms: Use of the MMPI-2 in medical assessments". International Journal of Clinical and Health Psychology; 4, 3 (2004): 571-595.

5. Samantha Mucci, Luciana Geocze, Denise CalutaAbranches, ,Normade Oliveira Penido. " Sys- 
tematic review of evidence on the association between personality and tinnitus". Braz J Otorhinolaryngol;80, 5 (2014):441-7

6. Green, Roger.The MMPI-2: An interpretative manual (2nd Ed.). Boston: Allyn and Bacon (2000).

7. Pop-Jordanova Nada, Polenakovic Momir. "Psychological characteristics of patients treated by chronic maintenance hemodialysis". Int J Artif Organs; 36, 2 (2013):77-86

8. Pop-Jordanova Nada. Eating Disorders in the Preadolescent Period: Psychological Characteristics and Biofeedback Mitigation, Chapter III in: Focus on Eating Disorder Research, 2003, Editor P. Swain, Nova Biomedical books, New York.

9. Pop-Jordanova Nada. "Psyhological characteristics and biofeedback mitigation in preadolescents with eating disorders', Pediatrics International; 1 (2000): 76-82

10. Pop-Jordanova Nada, Zorcec Tatjana. "Psychological characteristics of children with chronic diseases", Paediatr Croat; 52 (2008):71-76

11. Biederman Joseph, Habelow W, Rivinus T, Harmatz J, Wise J. "MMPI profiles in anorexia nervosa patients with and without major depression". Psychiatry Res;19, 2(1986): 147-54.

12. Blumenthal James, O’Toole Leslei, Chang Jonathan. "Is Running an Analogue of Anorexia Nervosa? An Empirical Study of Obligatory Running and Anorexia Nervosa". JAMA;252, 4(1984):520-523.

13. Goldberg Lewis. "Diagnosticians vs. diagnostic signs: the diagnosis of psychosis vs. neurosis from MMPI", Psychological Monographs; 79, 9 (1968).

\section{(5) Heart rate variability in the assess- ment and biofeedback training of anxious-pho- bic and $O C D$ children}

The cardiac system demonstrates continuous variations in heart rate. In recent research better understanding of the nature of these variations is acquired, postulating that more chaotic heart rates are healthier than the steadier ones. Heart rate variability (HRV) is a measure of the continuous interplay between sympathetic (SNS) and parasympathetic (PNS) influences on heart rate that yields information about autonomic flexibility and thereby represents the capacity for regulated emotional responding (Appelhans, 2006). HRV is direct psychophysiological measure for arousal, emotional state and stress level (Andreassi, 2000; Schwartz \& Andrasik, 2003).
The starting point of the frequency-based HRV analysis is the fact that the variations in heart rate produced by SNS and PNS activity occur at different speeds, or frequencies. SNS is slow acting and mediated by norepinephrine, while PNS influence is fast acting and mediated by acetylcholine.

Since the original report by Wolf et al. (1978) analysis of spontaneous variations of beat-to-beat intervals has become a valuable tool, familiar to clinical cardiologists. In 1987, Kleiger and co-workers published a pioneering work demonstrating that reduced heart rate variability was capable of identifying a subgroup of subjects with increased cardiac mortality after myocardial infarction and that its predictive value was independent of traditional clinical risk-stratifying factors. It was originally proposed that reduction in HRV might reflect an autonomic imbalance characterized by increased sympathetic and reduced vagal activity. This interpretation was also supported by indirect findings, showing a tendency toward faster heart rates and a smaller day-night heart rate difference observed in these patients.

Two major theories (polyvagal and neurovascular) causally relate autonomic flexibility, represented by HRV, and the capacity for regulated emotional responding (Appelhans and Luecken, 2006).

Polyvagal theory is based on an evolutionary explanation that the ANS has been developed in stages to deal with changes in the environment and respond effectively. The last component developed, the ventral vagus complex, physically connects with the facial muscles, voice production, and other socially important behaviours, which creates a physical connection between the heart and emotional expression.

Neurovascular integration theory gives an integrative explanation about evolutionary forces which led to the development of a rapidly responding vagus nerve to support appropriate emotional expression and regulation through connections with the cortex, limbic system, and brainstem. By inhibiting other potential responses through synaptic activity in the brain and vagal activity in the body, the central autonomic network acts as a neurophysiological command centre governing cognitive, behavioural, and physiological elements into regulated emotion states.

Both theories presented above are similar in that they (a) specify a critical role for para- 
sympathetically mediated inhibition of autonomic arousal in emotional expression and regulation and (b) maintain that HRV measures are informative about individuals' capacity for this aspect of regulated emotional responding.

Some empirical research with HRV (Coumel, 1991; Dreifus, et all. 1993; Kleiger, 2005) showed that:

- Higher levels of resting HRV have been associated with effective coping strategies er HRV

- Attention control is associated with high-

- Low HRV happened to be an independent risk factor for several negative cardiovascular outcomes

- Low HRV is a proxy for underlying cardiovascular disease processes

- Patients with generalized anxiety disorder show lower HRV than controls

- Low HRV has been associated with depression.

In clinical practice HRV training was used for prevention of cardiac diseases, to control high anxiety, depression and stress level, as well as to evaluate the stages of sleep (Haines, 1987; Kawachi, 1992, 1994, 1995; Agelink, 2002; Nahshoni, 2004; Song, 2003; Min-Young Chun, 2011, Sidharth A. 2013). Sharpley et all (2000) showed increased risk for cardiovascular disease related to rapid and dramatic increase in heart rate reactivity to a stressor task. In a more recent study (Ebben, 2009) HRV training was applied for diminishing sleep problems.

The clinical relevance of HRV in paediatrics was first appreciated in 1965 when Hon and Lee noted that foetal distress was preceded by alterations in interbeat intervals before any appreciable change occurred in heart rate itself. Thereafter, HRV training was applied in children with bronchial asthma, heart failures or brain damages (Massin, 1998; Gurjanova, 2008)

Various measures of heart rate variability have been proposed, which can roughly be subdivided into time domain and frequency domain (Amara, 1997). The calculation of the standard deviation of beat-to-beat intervals (the square of which is referred to as variance or mean power) is an example of a time domain measure. In other words, the time intervals between heart beats can be statistically analysed to obtain information about the autonomic nervous system. This approach includes root mean square of the dif- ferences between successive heart beat intervals (rMSSD), the number of normal to normal complexes greater than 50 milliseconds (NN50), and the percentage of total number of beats (pNN50).

A common frequency domain method is the application of the discrete Fourier transformation to the beat-to-beat interval time series. This provides an estimation of the amount of variation at specific frequencies. We used a similar procedure for calculation of EEG spectral power in the assessment of children with ADHD (Pop-Jordanova, 2009). In this context, concerning ECG spectra, several frequency bands of interest have been defined in humans.

The power spectrum of the HR is divided into four main frequency ranges. The ultra low frequency range (ULF) $(<0.003 \mathrm{~Hz})$ is the slowest component and can be measured only in long term ( 24 hours) recordings. The very low frequency range (VLF) (0.0033 to 0.04 $\mathrm{Hz}$, representing slower changes in heart rate measurable in shorter recordings, is an index of sympathetic activity, while power in the high frequency range (HF) $(0.15$ to $0.4 \mathrm{~Hz})$, representing quicker changes in heart rate, is primarily due to parasympathetic activity. The intermediate frequency range around the $0.1 \mathrm{~Hz}$ region is called the low frequency (LF) band and is often referred to as the bar receptor band, because it reflects the blood pressure feedback signals sent from the heart back to the brain, which also affect the HRV waveform. This band is more complex, as it can reflect a mixture of sympathetic and parasympathetic activity (Schwartz\&Andrasik, 2003).

Several factors influence the accuracy and usefulness of the measured HRV components. These include the duration of the recording and the effect of the various physical and physiological changes that occur during the recording period (Pagani, 1986; Friesen, 1990).

As a dynamic marker, HRV appears to be sensitive and responsive to acute stress. As a marker of cumulative life experience, HRV has also been shown to decline with the aging process. In short, HRV appears to be a marker of two processes: (1) frequent activation (short term dips in HRV in response to acute stress), and (2) inadequate response (long-term vagal withdrawal, resulting in the over-activity of the counter-regulatory system).

Heart Rate Variability (HRV) was applied in 15 anxious-phobic patients, mean age $12,5 \pm 2,25$ 
years and 10 children with obsessive-compulsive manifestations (OCD), mean age $14.5 \pm 2.20$; Results are compared with the control group of healthy children, matched by age and gender. The aim of this study was to evaluate HRV in the assessment and therapy of this groups of mental health problems in children.

The diagnosis is made according ICD-10 classification by the team consisting of paediatrician -psychophysiologist, clinical psychologist and child neurologist. All children were outpatients at the Paediatric Clinic, Faculty of Medicine, Skopje.

In the assessment procedure interviews with parents and children and psychometric evaluation with Eysenck Personality Questionnaire (EPQ) are used. EPQ is used for discriminating four main psychological characteristics of the personality: extraversion/ introversion; neurotic tendencies/ stability; psychopathologic traits/ normal behaviour and control liescale. Most important for the study was to discriminate extravert/ introvert children which is significant for mental arousal (Pop-Jordanova and Pop-Jordanov, 2005).

Eysenck Personality Questionnaire (EPQ) is a self-report personality inventory which assumes three basic factors (the two most important being extraversion to introversion and neuroticism). In the previous studies we used this instrument for differentiation of the personality traits in children with chronic diseases (Pop-Jordanova, 2008), mental anorexia and adiposity (Pop-Jordanova, 2000) as well as somatoform disorders and ADHD (Pop-Jordanova, 2009). For the clinical analyses, we developed a com- puter-based expert system. The stability, validity and reliability of scales in EPQ was confirmed in many other studies.

We used Heart Math Freeze-Framer System (1998) as biofeedback instrumentation. This relatively simple system is constructed to help in the following area: to shift intentionally to more positive emotional state; to help in better problem solving; to maintain general health and physical resilience; to transform the stress into positive relationships and to help in effective dealing with stress. It is supposed that effective emotional regulation depends on being able to flexibly adjust the physiological response to a changing environment.

The patients were sitting in a comfortable chair, in a quiet room, along with the practitioner. The instruction was: be calm, breathe deeply and try to think about pleasant situations or persons. After the assessment, 15 training sessions are applied. The dynamics of HRV changes during one whole session for one patient is presented in Figure 1.

The obtained results were statistically elaborated with: ANOVA for first and last sessions of all groups and Student t-test for differences between groups (Word package Statistics 10). The applied biofeedback system shows heart rate changes during every training session. The duration of all sessions is about 16 minutes and included basic recording and two games (meadow and balloon). Calculated mean values and standard deviations of the first and last session are used for t-test. In addition, the system shows the high, mean and low entertainment level ratio in every session.

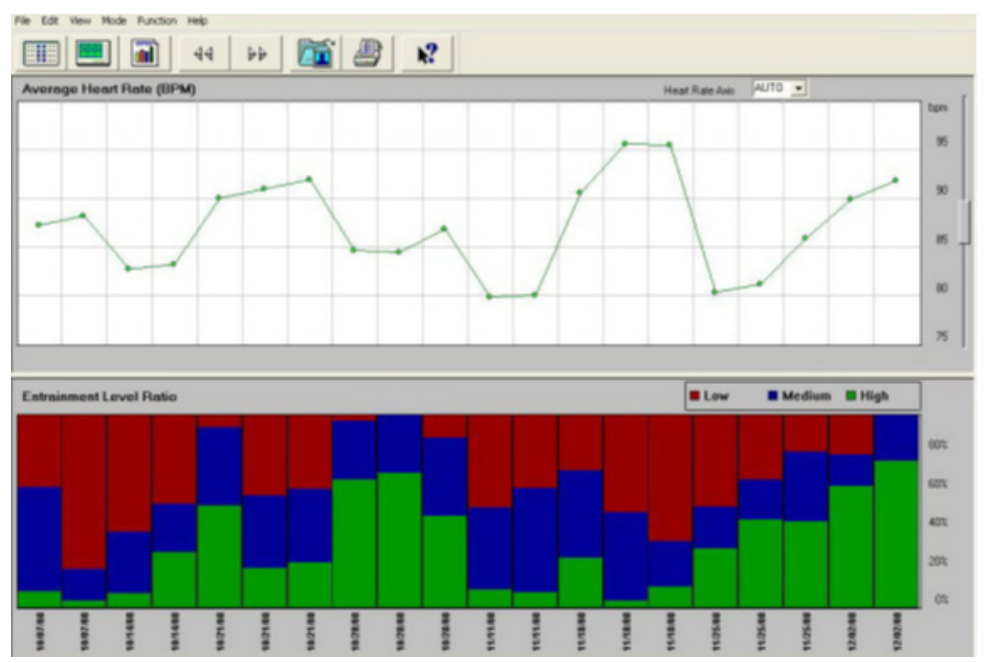

Fig. 1. Screenplay for Heart Math Freeze-Framer System 
Results obtained for EPQ for the examined group of children are presented in Table 1.

Table 1. Results obtained for EPQ

\begin{tabular}{|c|c|c|c|}
\hline $\begin{array}{l}\stackrel{0}{0} \\
\ddot{U}\end{array}$ & 离 & ঠે & 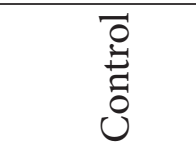 \\
\hline $\mathrm{P}$ & $\begin{array}{l}5.82 \pm 2.12 \\
p=0.27\end{array}$ & $\begin{array}{l}6.25 \pm 2.94 \\
p=0.3\end{array}$ & $4.86 \pm 2.09$ \\
\hline $\mathrm{E}$ & $\begin{array}{l}14.36 \pm 5.15 \\
p=0.062\end{array}$ & $\begin{array}{l}14.75 \pm 2.27 \\
p=0.72\end{array}$ & $17.2 \pm 1.42$ \\
\hline $\mathrm{N}$ & $\begin{array}{l}14.45 \pm 3.79 \\
p=0.13\end{array}$ & $\begin{array}{l}13 \pm 4 \\
p=0.02 *\end{array}$ & $12.2 \pm 3.38$ \\
\hline $\mathrm{L}$ & $\begin{array}{l}14.27 \pm 3.0 \\
p=0.098\end{array}$ & $\begin{array}{l}11.5 \pm 2.69 \\
p=0.03 *\end{array}$ & $16.13 \pm 2.29$ \\
\hline & $\begin{array}{l}* \mathbf{P}<\mathbf{0 . 0 5} ; * * \\
\mathrm{P}=\text { psychop } \\
\mathrm{E}=\text { extraversi } \\
\mathrm{N}=\text { neurotic } \\
\mathrm{L}=\text { lie scale }\end{array}$ & $\begin{array}{l}\mathbf{P}<\mathbf{0 . 0 0 5} \\
\text { thological tra } \\
\text { n; } \\
\text { ndencies; }\end{array}$ & \\
\hline
\end{tabular}

Generally, both groups of children (anxious-phobic and obsessive-compulsive) showed lower scores for extraversion and higher scores for neuroticism, compared to the control group. It can be supposed that all these children have higher inner mental arousal compared with healthy children. It means that "brain-rate" (spectrum-weighted frequency) is higher in eyes closed than in eyes open condition (Pop-Jordanova and Pop-Jordanov, 2005). This finding is important for the choice of biofeedback modality. Namely, for introvert personalities, manifesting so called "inner arousal" (calculated with brain-rate formula), the application of peripheral biofeedback modalities is a better choice. In this context peripheral biofeedback based on HRV was chosen also for this study. The aim of HRV training is to obtain higher HRV, shifting simultaneously the EEG spectrum toward lower frequency range.

Anxiety group (Fig. 3) showed very good results concerning HRV; they diminished the low and raised the high HRV scores.

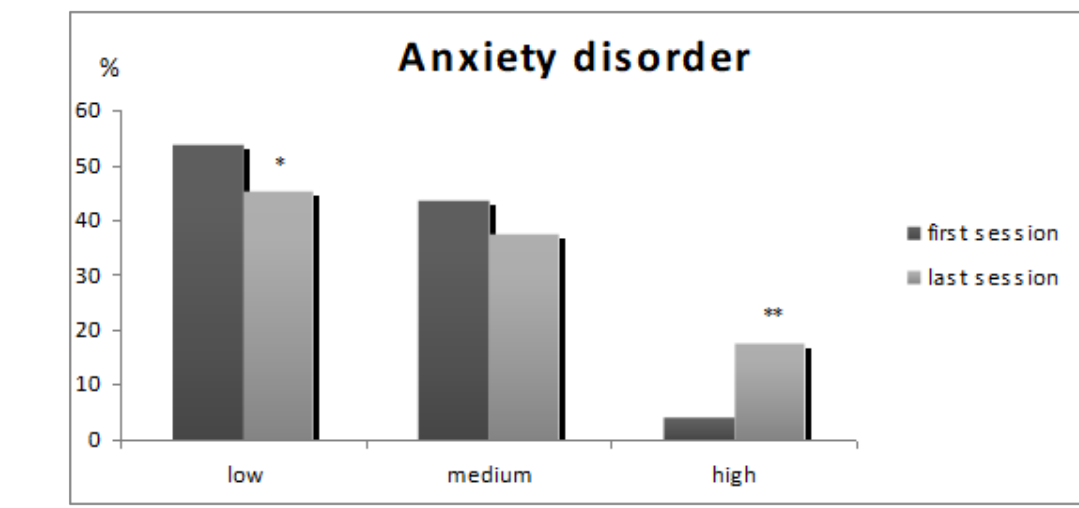

$* \mathrm{p}<0.05 ;{ }^{* *} \mathrm{p}<0.01 \quad$ Fig 3. HRV spectra for children with anxiety

Changes of HRV in the OCD group are presented in Figure 5. It is clear that with the training children learned to obtain higher medium and high part of spectra which is important for the clinical outcome.

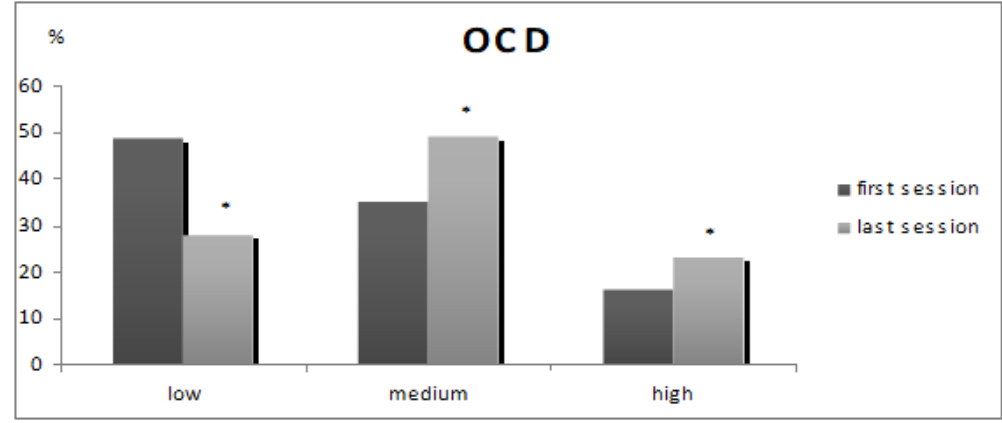

Fig 4. HRV spectra in children with obsessive-compulsive disorder 
Table 2. ANOVA for low, medium and high HRV, the first and last session

\begin{tabular}{|c|c|c|c|c|c|c|c|c|}
\hline & & & & & & & & \\
\hline & $\underline{\mathrm{SS} \text { effect }}$ & df effect & $\underline{\text { ms effect }}$ & $\underline{\text { ss error }}$ & df error & $\underline{\text { ms error }}$ & $\underline{f}$ & $\mathrm{p}$ \\
\hline$\underline{\text { low first }}$ & $\underline{60.82}$ & $\underline{34}$ & 1.78 & $\underline{13.66}$ & $\underline{6}$ & $\underline{2.27}$ & $\underline{0.78}$ & $\underline{0.7}$ \\
\hline$\underline{\text { medium first }}$ & $\underline{48.48}$ & $\underline{30}$ & $\underline{1.61}$ & 26 & $\underline{10}$ & 2.6 & $\underline{0.62}$ & $\underline{0.84}$ \\
\hline high first & $\underline{41.98}$ & $\underline{17}$ & $\underline{2.46}$ & $\underline{32.5}$ & $\underline{23}$ & $\underline{1.41}$ & $\underline{1.74}$ & $\underline{0.1}$ \\
\hline low last & $\underline{58.82}$ & $\underline{29}$ & $\underline{2.02}$ & $\underline{15.66}$ & $\underline{11}$ & $\underline{1.42}$ & $\underline{1.42}$ & $\underline{0.27}$ \\
\hline$\underline{\text { medium last }}$ & $\underline{61.15}$ & $\underline{30}$ & 2.03 & 13.33 & $\underline{10}$ & $\underline{1.33}$ & $\underline{1.52}$ & $\underline{0.24}$ \\
\hline$\underline{\text { high last }}$ & $\underline{51.07}$ & $\underline{20}$ & 2.55 & 23.41 & $\underline{20}$ & $\underline{1.17}$ & $\underline{2.18}$ & $\underline{0.044}$ \\
\hline
\end{tabular}

Additionally, not significant correlations between age and low, medium, and high HRV are obtained. As well as, no correlations between age and scores obtained from EPQ were found.

The zone-accumulated entrainment score shows the percentage of successfulness (high HRV) during all training sessions (Table 3). The maximum is $100 \%$ which is practically impossible to reach. However, the higher score means more successful changes in long duration of HRV.

Table 3. Results for zone-accumulated score (\%)

\begin{tabular}{|l|l|}
\hline Disorder & the zone-accumulated entrainment score \\
\hline Anxiety & 30 \\
\hline OCD & 20 \\
\hline
\end{tabular}

The results obtained with biofeedback calculated directly through the instrument happened to be the best in the group with general anxiety (30), but it is also good for OCD (20).

In general, this study shows that HRV as a peripheral biofeedback could be a good choice, especially for introvert children manifesting anxiety and obsessive-compulsive disorder. The application is non-invasive, has good cost-benefit and the included games are very interesting for children.

\section{REFERENCES}

1. Appelhans, Bradley, Luecken, Linda. "Heart Rate Variability as an Index of Regulated Emotional Responding". Review of General Psychology. 10 (2006):229-24

2. Andreassi John L. Psychophysiology, Human Behaviour and Physiological Response, Lawrence Erlbaum Associates Pub., London (2000)

3. Mark S. Schwartz, Frank Andrasik. Biofeedback, Third Edition: A Practitioner's Guide, 2003, Guilford Publication.

4. Wolf MM., Varigos GA., Hunt D., Sloman JG. "Sinus arrhythmia in acute myocardial infarction”, Med.J Aust; 2 (1978): 52-53
5. Robert Kleiger, Philip Miller, Thomas Bigger, Arthur Moss. "Decreased heart rate variability and its association with increased mortality after acute myocardial infarction", The American Journal of Cardiology; 68, 6 (1991): 626-630.

6. Kleiger Robert, Stein Phylis, Thomas Bigger "Heart rate variability: measurement and clinical utility". Ann Non-invasive Electrocardiol.;10, 1 (2005):88-101.

7. Appelhans Bradly, Luecken, Linda. "Heart rate variability as an index of regulated emotional responding". Review of General Psychology; 10, 3 (2006): 229-240.

8. Coumel PH., Hermida JS., Wennerblöm B., Leenhardt A., Maison-Blanche P., Cauchemez B. "Heart rate variability in myocardial hypertrophy and heart failure, and the effects of beta-blocking therapy: a non-spectral analysis of heart rate oscillations". Eur Heart J., 12 (1991): 412-422

9. Leonard S.Dreifus, Jai B.Agarwal, Elias H.Botvinick, Keith C.Ferdinand, Charles Fisch, John D.Fisher, Ward Kennedy, Richard E.Kerber, Charles R.Lambert, Okike N.Okike, Eric N.Prystowsky, Sanjeev V.Saksena, John S.Schroeder, David O.Williams, (American College of Cardiology Cardiovascular Technology Assessment Committee) . "Heart rate variability for risk stratification of life-threatening arrhythmias". J Am Coll Cardiol 22 (1993):948-950

10. Haines AP., Imeson JD., Meade TW. "Phobic anxiety and ischemic heart disease". Br Med J 295 (1987): 297-299.

11. Ichiro Kawachi, Graham A. Colditz, Alberto Ascherio, Eric B. Rimm, Edward Giovannucci, Meir J. Stampfer, Walter C. Willett." Prospective study of phobic anxiety and risk of coronary heart disease in men". Circulation.;89 (1994):19921997

12. Marcus W. Agelink, Cavit Boz, Heiko Ullrich, Jurgen Andrich. "Relationship between major depression and heart rate variability. Clinical consequences and implications for antidepressive treatment". Psychiatry Research, 113 (2002):139-149. 
13. Eitan Nahshoni, Dan Aravot, Dov Aizenberg, Abraham Weizman et al. "Heart Rate Variability in Patients With Major Depression" Psychosomatics 45, 2 (1991):129-34

14. Hye-Sue Song, Paul M. Lehrer. "The effects of specific respiratory rates on heart rate and heart rate variability", Applied Psychophysiology and Biofeedback, 28, 1 (2003): 13-23

15. Gabriell E. Prinsloo,H. G. Laurie Rauch, Michael I. Lambert, Frederick Muench, Timothy D. Noakes , Wayne E. Derman. "The effect of short duration heart rate variability (HRV) biofeedback on cognitive performance during laboratory induced cognitive stress". Cognitive Psychology, 25, 5 (2011): 792-801.

16. Min-Young Chun, Hoon-Ki Park, Hwan-Sik Hwang, Jae-Il Han, Young-Joon Chee, and JongSill Lee. "The Association between Symptoms of Autonomic Neuropathy and the Heart Rate Variability in Diabetics". Korean J Fam Med.; 32, 5(2011): 292-298.

17. Sidharth A. Shah, Thomas Kambur, Cheeling Chan, David M. Herrington, Kiang Liu, Sanjiv J. Shah. "Relation of Short-Term Heart Rate Variability to Incident Heart Failure (From the Multi-Ethnic Study of Atherosclerosis)". Am J Cardiol; 112, 4(2013): 533-540.

18. Sharpley CF, Kamen P, Galatsis M, Heppel $\mathrm{R}$, Veivers $\mathrm{C}$, Claus K. "An examination of the relationship between resting heart rate variability and heart rate reactivity to a mental arithmetic stressor". Appl Psychophysiol Biofeedback.;25, 3(2000):143-53.

19. Matthew R. Ebben, Vadim Kurbatov, Charles P. Pollak." Moderating laboratory adaptation with the use of a heart-rate variability biofeedback device (StressEraser)".Applied Psychophysiology and Biofeedback, 34, 4(2009): 245-249

20. Hon EH., Lee ST. "Electronic evaluations of the foetal heart rate patterns preceding foetal death: further observations". Am J Obstet Gynecol ;87 (1965):814-826.

21. Massin MM, Derkenne B., von Bermuth G. „Heart rate behaviour in children with atrial septal defect", Cardiology, 90, 40 (1998): 269-273

22. Gurjanova YM., Igisheva LN., Galeev AP. "Some feature of Heart rate variability in children with bronchial asthma", Kemerovo State Medical Academy, Russia, HRV Congress.org (2008)

23. Amara, C. E., \& Wolfe, L. A. "Reliability of non-invasive methods to measure cardiac autonomic function". Canadian Journal of Applied Physiology; 20, (1998):396-408
24. Pop-Jordanova Nada. "Biofeedback application for somatoform disorders and attention deficit hyperactivity disorder (ADHD) in children", International Journal of Medicine and Medical Sciences; 1, 2(2009): 17-22.

25. Raffaello Furlan, Stefano Guzzetti, Wilma Crivellaro, Simonetta Dassi, Mauro Tinelli, Giuseppe Baselli, Sergio Cerutti, Federico Lombardi, Massimo Pagani, Alberto Malliani.'Power spectral analysis of heart rate and arterial pressure variabilities as a marker of sympatho-vagal interaction in man and conscious dog". Circ Res.;59, 2 (1986):178-93.

26. Gary M. Friesen, Thomas C. Jannett, Manal Afify Jadallah, Stanford L. Yates, Stephen R. Quint, and H. Troy Nagle. "A comparison of the noise sensitivity of nine QRS detection algorithms". IEEE Trans Biomed Eng. 37 (1990):85-98.

27. Pop-Jordanova Nada. "Psychological characteristics and biofeedback mitigation in preadolescents with eating disorders", Paediatrics International; 42, 1(2000): 76-82.

28. Pop-Jordanova Nada. "Eating Disorders in the Preadolescent Period: Psychological Characteristics and Biofeedback Mitigation", Chapter III in: Focus on Eating Disorder Research, Editor P. Swain, Nova Biomedical books, New York.(2003).

29. Pop-Jordanova Nada, Pop-Jordanov Jordan. "Spectrum Weighted EEG Frequency ("Brainrate") as a Quantitative Indicator of Mental Arousal", Prilozi, 26, 2 (2005): 35-42.

30. Pop-Jordanova Nada, Zorcec Tatjana. "Psychological characteristics of children with chronic diseases", Paediatr Croatica, 52 (2008):71-76.

31. Pop-Jordanova Nada. "Biofeedback application in somatoform disorders and ADHD in children", International Journal of Medicine and Medical Sciences, 1, 2 (2009): 17-22.

32. Heart Math Freeze-Framer System, A Scientifically Proven Technique for Clear Decision Making and Improved Health, DOC Children, Planetary Publications, Boulder Creek, CA. Edited by Bruce Cryer. (1998)

33. Heart rate variability: standards of measurement, physiological interpretation and clinical use. Task Force of the European Society of Cardiology and the North American Society of Pacing and Electrophysiology. Circulation. 1996;93:1043-1065.

34. Leah Lagos, Thomas Bottiglieri, Bronya Vaschillo, and Evgeny Vaschillo. "Heart Rate Variability Biofeedback for Postconcussion Syndrome: Implications for Treatment" Biofeedback Association for Applied Psychophysiology \& Biofeedback; 40, 4 (2012): 150-153. 


\title{
Резиме
}

\section{РАЗЛИЧНИ КЛИНИЧКИ МАНИФЕСТАЦИИ НА АНКСИОЗНО РАСТРОЈСТВО КАЈ ДЕЦА И КАЈ АДОЛЕСЦЕНТИ: ПРОЦЕНА И ТРЕТМАН}

\section{Нада Поп-Јорданова}

\author{
Македонска академија на науките и уметностите, Скопје, Република Македонија
}

Анксиозното однесување и однесувањето исполнето со страв е често кај децата, особено кога тие минуваат низ нови ситуации и искуства. Разликата меѓу нормалната грижа и анксиозноста се состои во силата и интерференцијата со секојдневните животни активности и нормалните развојни стапки. Многу лонгитудинални студии сугерираат дека анксиозните растројства се релативно стабилни со текот на времето и предвидуваат анксиозност и депресивно растројство во адолесценцијата и во возрасниот период. Поради тоа, раната дијагноза и третман се неопходни.

Истражувачите претпоставуваат дека е анксиозноста резултат на повторувачки стрес. Дополнително, некои генетски, невробиолошки и развојни фактори се вклучени во етиологијата.

Целта на овој напис е сумирање и приказ на сопствените резултати добиени при процена и третман на разни форми на анксиозно растројство кај децата и кај адолесцентите, какви што се: Посттравматското стресно растројство (ПТСД), опсесивно-компулсивното растројство (ОЦД), денталниот страв, генерализираното анксиозно растројство (ГАД) и анксиозно-фобичниот синдром. Некои резултати се публикувани одделно во разни списанија.

Резултати:

а) Посттрауматското стресно растројство кај 10 деца со средна возраст $9 \pm 2,05$ год. е евалуирано и добиените резултати се дискутирани преку квалитетот на раното емоционално врзување.

б) Група деца со опсесивно-компулсивно растројство, средна возраст 14,5 $\pm 2,2$ год. е испитувана со помош на Eysenck Personality Questionnaire (EPQ), Child behavior Checklist (CBCL), K-SADS (Schedule for Affective Disorders and Schizophrenia for School age children), Beck Depression и добиените резултати се дискутирани.

в) Испитуван е дентален стрес кај 50 деца со средна возраст $11,4 \pm 2,4$ год. на девојчињата и $10,7 \pm 2,6$ год. на момчињата со користење на Генерална скала за анксиозност (GASC) и Ајзенков инвентар на личноста ( EPQ).

г) Профилите добиени со Minnesota Multiphasic Personality Inventory (MMPI) кај 20 млади жени со генерализирана анксиозност, на возраст 25,7 $\pm 5,35$ год. и кај 15 пациенти со панични атаки на возраст 19,3 $\pm 4,9$ год. се презентирани како слики и дискутирани.

д) Варијабилноста на срцевиот ритам (ХРВ) е применетаа кај 15 анксиозно-фобични пациенти, на средна возраст $12,5 \pm 2,25$ год., и добиените резултати се споредени со други групи ментални растројства.

Резултати: Децата со ПТСД покажаа високо ниво на анксиозност и стрес, соматизација и проблеми со однесувањето (агресивност, импулсивност, непослушност и ноќни стравови), надополнето со хиперсензитивни и депресивни мајки и лошо емоционално врзување во раниот период на животот. Последователно, објаснувањето за раната предиспозиција за ПТСД беше засновано на неразвивање на десниот орбитофронтален кортекс, што е условено од несигурно емоционално врзување кај сите испитувани деца.

Добиените невропсихолошки профили кај децата со ОЦД потврдија јасно присуство на опсесии и компулсии, средно интелектуално ниво и отсуство на депресивни симптоми. Егзекутивните функции беа испитувани со Потенцијали провоцирани со настан (ЕРП) преку парадигмата Го/НоГо. Резултатите покажаа незначителна промена на когнитивните функции во овој ран период, со можност на влошување во текот на идниот развоен период, доколку проблемот не се лекува навремено.

Во студијата кај 50 деца по случаен избор, со помош на два психометриски инструменти, мерена е општата анксиозност и карактеристиките на личност. Покажано е со помош на ГАСК високо ниво на анксиозност кај децата кај кои следувала дентална интервенција. Девојчињата се со повисока анксиозност од момчињата. Резултатите од EPQ потврдија ниски скорови за психопа- 
тологија, умерена екстраверзија и невротичност, додека скоровите на Л-скалата растат со возраста, што се поврзува со промените од пубертетот. Не беа најдени корелации меѓу добиените скорови на EPQ и нивото на анксиозност, освен за скоровите за невротичност.

Кај пациентите со генерализирана анксиозност, добиените профили на MMPI се прикажани како слики. Женските пациенти покажаа нагласен Ну пик, но во нормални рамки. Сепак, статистиката покажа значајни разлики меѓу анксиозните пациенти и контролната група ( $\mathrm{t}=2,25164 ; \mathrm{p}=0,038749)$. Машките покажаa Hs-Hy-Pt пикови со патолошки вредности, поврзани со хиперсензитивноста на автономниот нервен систем, како и со манифестната анксиозност. Пресметаната статистичка значајност ја потврдува разликата меѓу машките пациенти и контролната група $(\mathrm{t}=15.13, \mathrm{p}=0.000)$.

MMPI профилите кај пациенти со панични напади се прикажани како слики. Контролните скали кај жените покажаа типична V-форма (скали 1 и 3), поврзана со конверзивни тенденции. Дополнително, жените покажаа пикови на Pt-Sc скалите, но во нормални вредности. Патолошки профили се добиени кај мажите со Нy-Sc пикови, кои одговараат на личности со регресивни особености, емоционална нестабилност и нагласена социјална отуѓеност.

Варијабилноста на срцевиот ритам (XРВ) претставува мерка за работата на автономниот нервен систем. Може да служи како психофизиолошки индикатор на возбуденоста, емоционалната состојба и нивото на стрес. Ние го користевме ХРВ во процената и биофидбек-тренингот на група со акксиозно-фобични и опсесивно-компулсивни растројства кај школски деца. Резултатите добиени со Ајзенковиот профил на личност покажаа повисоки психопатолошки скорови, повисока невротичност и пониски скорови на Л-скалата. По 15 сесии ХРВ-тренинг, добиени се многу задоволитетлни резултати и намалување на стресот и анксиозноста.

Клучни зборови: анксиозност, клинички знаци, деца, адолесцент, процена, третман 